\title{
Receptor modeling of near-roadway aerosol mass spectrometer data in Las Vegas, Nevada, with EPA PMF
}

\author{
S. G. Brown ${ }^{1,2}$, T. Lee ${ }^{2}$, G. A. Norris ${ }^{3}$, P. T. Roberts ${ }^{1}$, J. L. Collett, Jr. ${ }^{2}$, P. Paatero ${ }^{4}$, and D. R. Worsnop \\ ${ }^{1}$ Sonoma Technology, Inc., Petaluma, California, USA \\ ${ }^{2}$ Colorado State University, Atmospheric Science Department, Fort Collins, Colorado, USA \\ ${ }^{3}$ U.S. EPA, Office of Research and Development, Research Triangle Park, North Carolina, USA \\ ${ }^{4}$ University of Helsinki, Dept. of Physics, Helsinki, Finland \\ ${ }^{5}$ Aerodyne Research, Billerica, Massachusetts, USA
}

Correspondence to: S. G. Brown (sbrown@ sonomatech.com)

Received: 1 June 2011 - Published in Atmos. Chem. Phys. Discuss.: 15 August 2011

Revised: 12 December 2011 - Accepted: 19 December 2011 - Published: 5 January 2012

\begin{abstract}
Ambient non-refractory $\mathrm{PM}_{1}$ aerosol particles were measured with an Aerodyne High Resolution Timeof-Flight Aerosol Mass Spectrometer (HR-AMS) at an elementary school $18 \mathrm{~m}$ from the US 95 freeway soundwall in Las Vegas, Nevada, during January 2008. Additional collocated continuous measurements of black carbon (BC), carbon monoxide $(\mathrm{CO})$, nitrogen oxides $\left(\mathrm{NO}_{\mathrm{x}}\right)$, and meteorological data were collected. The US Environmental Protection Agency's (EPA) positive matrix factorization (PMF) data analysis tool was used to apportion organic matter (OM) as measured by HR-AMS, and rotational tools in EPA PMF were used to better characterize the solution space and pull resolved factors toward known source profiles. Three- to sixfactor solutions were resolved. The four-factor solution was the most interpretable, with the typical AMS PMF factors of hydrocarbon-like organic aerosol (HOA), low-volatility oxygenated organic aerosol (LV-OOA), biomass burning organic aerosol (BBOA), and semi-volatile oxygenated organic aerosol (SV-OOA). When the measurement site was downwind of the freeway, HOA composed about half the OM, with SV-OOA and LV-OOA accounting for the rest. Attempts to pull the PMF factor profiles toward source profiles were successful but did not qualitatively change the results, indicating that these factors are very stable. Oblique edges were present in G-space plots, suggesting that the obtained rotation may not be the most plausible one. Since solutions found by pulling the profiles or using $F_{\text {peak }}$ retained these oblique edges, there appears to be little rotational freedom in the base solution. On average, HOA made up $26 \%$ of the OM, while LV-OOA was highest in the afternoon and accounted for $26 \%$ of the OM. BBOA occurred in the evening hours, was predominantly from the residential area to the north, and
\end{abstract}

on average constituted $12 \%$ of the OM; SV-OOA accounted for the remaining third of the OM. Use of the pulling techniques available in EPA PMF and ME-2 suggested that the four-factor solution was very stable.

\section{Introduction}

A number of studies have demonstrated the significant health impacts of air pollution such as particulate matter of aerodynamic diameter less than 2.5 microns $\left(\mathrm{PM}_{2.5}\right)$, including increased asthma rates, detrimental fetal development during pregnancy, and decreased lung capacity (Brunekreef et al., 1997; McDonald et al., 2004; Dockery et al., 1993; Dockery and Stone, 2007). In particular, recent literature has demonstrated that adverse health effects are evident in subjects exposed to ambient air near major roadways (Edwards et al., 1994; Nitta et al., 1993; Kunzli et al., 2000; Hoek et al., 2002; Finkelstein et al., 2004; Kim et al., 2004b). A wide body of literature of previous near-roadway air pollution studies (Zhu et al., 2002; Zhang et al., 2004a; Phuleria et al., 2007; Ntziachristos et al., 2007; Fruin et al., 2008) has demonstrated that, for a number of pollutants such as black carbon (BC), carbon monoxide (CO), and ultrafine particles, concentrations are very high next to the freeway but rapidly decrease to background urban levels after a few hundred meters under persistent winds. In pre-sunrise hours and low wind conditions, the influence of freeway emissions can reach even further (Hu et al., 2009).

Organic matter (OM) is a large and important part of $\mathrm{PM}_{2.5}$, particularly in near-roadway environments, and is often the largest component of PM in urban areas in the 
western United States (Phuleria et al., 2007; Riddle et al., 2008; Minguillon et al., 2008). OM is a complicated mixture of thousands of individual molecules and is a combination of both primary particulate emissions and secondary aerosol formed from gaseous precursors. It is a major component of vehicular exhaust emissions and, in addition to being a large part of $\mathrm{PM}_{2.5}$ mass, also includes polycyclic aromatic hydrocarbons (PAHs), which are carcinogenic (Larsen and Baker, 2003; Lobscheid and McKone, 2004; Adonis et al., 2003; Flowers et al., 2002).

The composition of OM has been analyzed under a number of different methods, including molecular marker analysis of aerosol filter samples and real-time analysis with instruments such as the Aerodyne Aerosol Mass Spectrometer (AMS) and its more recent version, the High Resolution Time-of-Flight Aerosol Mass Spectrometer (HR-AMS) (Drewnick et al., 2005; Jimenez et al., 2003; Zhang et al., 2005a; Allan et al., 2004, 2003a, 2003b; DeCarlo et al., 2006). With the AMS, individual molecular marker compounds are not typically quantified, but with this loss of molecular specificity we gain high time resolution and a more complete representation of the full organic fraction. Rather than individual molecules, specific groups of mass-to-charge ratio fragments $(\mathrm{m} / z)$ can be used to identify differences between less oxidized, hydrocarbon-like organic aerosol (HOA) and oxygenated organic aerosol (OOA). Some examples include data from Pittsburgh, Pennsylvania (Zhang et al., 2004b, 2005a, b), Riverside, California (Docherty et al., 2008), Zurich (Lanz et al., 2008a, 2007), Mexico City (Dzepina et al., 2007; Johnson et al., 2008; Aiken et al., 2008), and Fraser Valley, British Columbia (Alfarra et al., 2007, 2004).

Laboratory and field studies have found that $m / z 44$ (i.e., $\mathrm{CO}_{2}^{+}$) is a major fragment when long range transport is important and during periods of active photochemistry and that $m / z 44$ is representative of OOA. In prior field studies in Pittsburgh, British Columbia, and elsewhere (Zhang et al., 2004b, 2005a, b; Alfarra et al., 2007, 2004), saturated hydrocarbon fragments such as $m / z 57$ (i.e., $\mathrm{C}_{4} \mathrm{H}_{9}^{+}$) were found to be typical of HOA.

AMS data have, in recent years, been further evaluated with positive matrix factorization (PMF) or other mathematical methods (Zhang et al., 2004b, 2005a, b) to decompose the mass spectra and quantify the amount of OOA and HOA impacting a monitoring site. Source studies of primary emissions-such as diesel exhaust in a vehicle-chasing experiment (Canagaratna et al., 2004), source profile acquisition (Mohr et al., 2009), and reaction chamber secondary OA (SOA) (Alfarra et al., 2006)-show similarities to spectra from ambient aerosol. These two types of primary OA (POA) and SOA profiles resemble those observed in the ambient air under conditions more conducive to primary (high $\mathrm{m} / z 57$ concentrations) and secondary (high $\mathrm{m} / \mathrm{z} 44$ concentrations) influences, respectively. In addition, two types of OOA spectra have been observed in Riverside and elsewhere
(Docherty et al., 2008; Huffman et al., 2009; Jimenez et al., 2009), one with more "low volatility" fragments (LV-OOA) including $m / z$ 44, but also one with significant mass from other, less oxidized fragments. This spectrum has also been observed in chamber experiments with diesel exhaust and resembles semi-volatile OA with some oxidized OA, termed SV-OOA.

\section{Methods}

\subsection{Aerosol and gaseous measurements}

Measurements were made outdoors next to a classroom and play yard at Fyfe Elementary School, directly adjacent to and $18 \mathrm{~m}$ from the US 95 soundwall (Fig. 1). In 2007, the annual average daily traffic (AADT) was between 189000 and 201000 vehicles on the stretch of US 95 near Fyfe Elementary School. The wind sector from 90 to 250 degrees encompasses the adjacent freeway. $\mathrm{CO}, \mathrm{NO}_{\mathrm{x}}$, Aethalometer $\mathrm{BC}$, wind speed, and wind direction were measured continuously, yielding 5-min averages. A two-channel $(370 \mathrm{~nm}$ and $880 \mathrm{~nm}$ ) Magee Scientific Aethalometer was used to measure BC in 5-min intervals. Aerosol was collected on a glass fiber tape, passing through a Harvard impactor with a size-cut of 2.5 microns. Raw data were post-processed with the Washington University Air Quality Lab AethDataMasher Version 6.0e to format date-time stamps and perform data validation. A Thermo Scientific $42 \mathrm{i} \mathrm{NO} / \mathrm{NO}_{2} / \mathrm{NO}_{\mathrm{x}}$ analyzer and a Thermo Scientific 48i CO analyzer provided 5-min $\mathrm{NO}_{\mathrm{x}}$ and $\mathrm{CO}$ data. Zero-checks and span-checks were performed nightly; data were zero-corrected if the zero-check was greater than $5 \%$ of expected. Continuous gaseous instruments were calibrated at setup, take down, and quarterly, plus on an as-needed basis via remote control over the internet. Five-minute data were visually reviewed daily and after the study for additional QC. Wind speed and direction were measured with an RM Young AQ 5305-L at 1-min intervals, and were used to calculate vector-averaged 5-min average data.

\subsection{HR-AMS description and data processing}

The operation of the Aerodyne HR-AMS has been described in detail elsewhere (DeCarlo et al., 2006; Drewnick et al., 2005; Jayne et al., 2000; Jimenez et al., 2003, 2009). Ambient air is drawn through a URG cyclone $\left(D_{50}=2.5 \mu \mathrm{m}\right.$, $3 \mathrm{lpm}$ ) and is sampled with 2-min time resolution through a critical orifice into an aerodynamic lens, creating a narrow particle beam, with a $50 \%$ efficiency of $1 \mu \mathrm{m}$ particles, so that essentially $\mathrm{PM}_{1}$ is measured (Sun et al., 2009; Canagaratna et al., 2007). The particles are accelerated in the supersonic expansion of gas molecules into a vacuum at the end of the lens. Particles are collected by inertial impaction and non-refractory species such as nitrate, sulfate, ammonium, chloride, potassium and $\mathrm{OM}$ are thermally vaporized. 


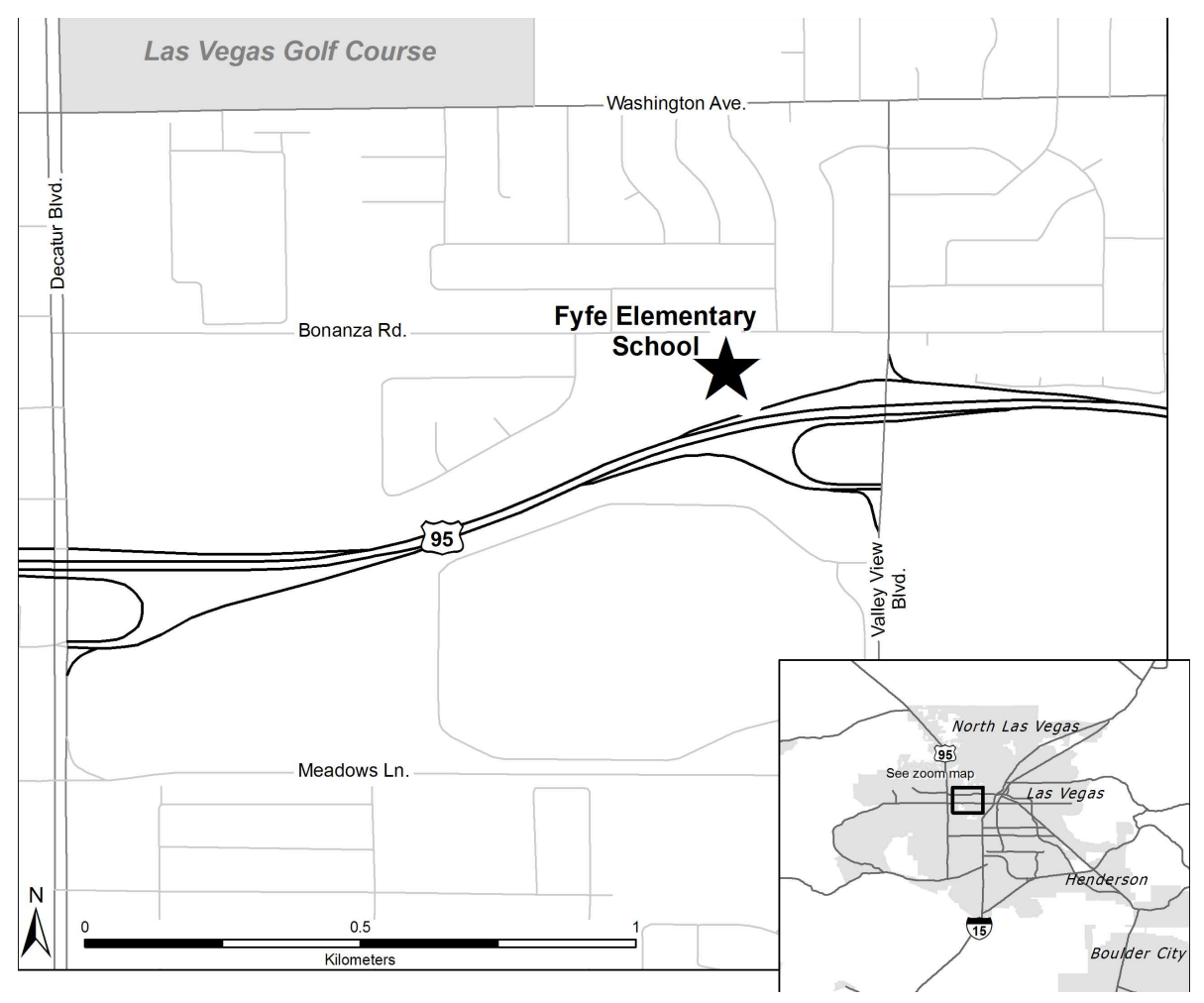

(a)

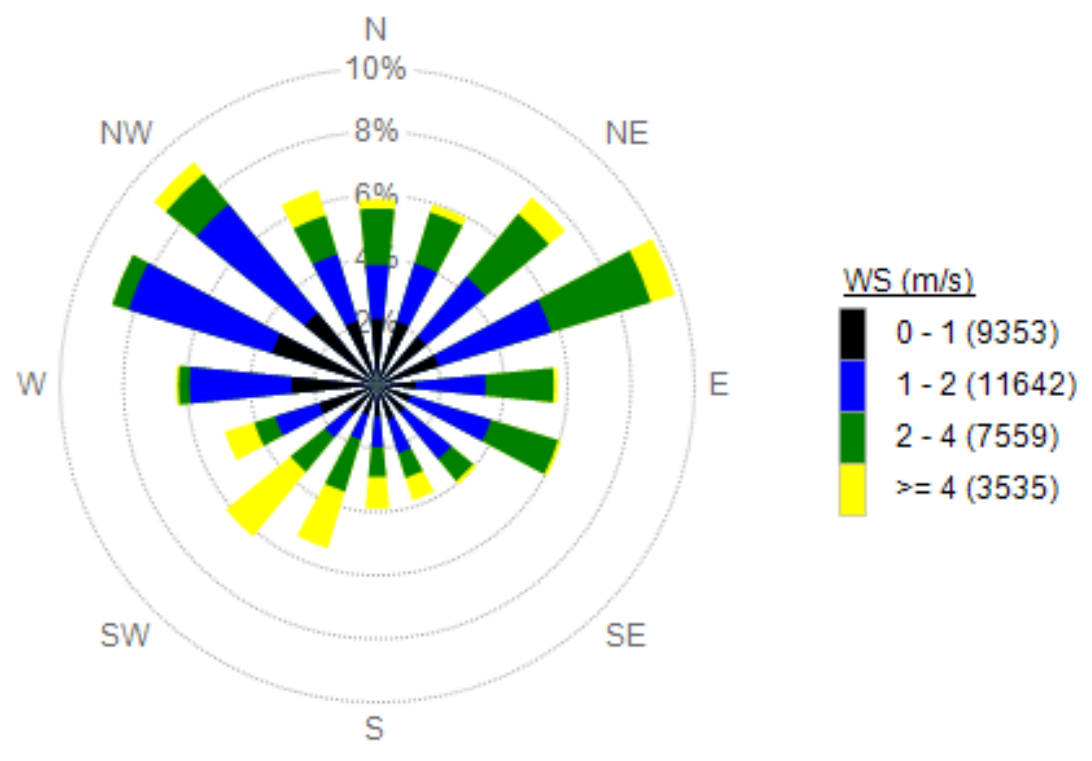

(b)

Fig. 1. (a) location of Fyfe Elementary School in Las Vegas, Nevada; and (b) wind rose for January 2008 (5-min averages).

Vaporized gases undergo electron impact ionization and the charged fragments enter the ToF-MS region, where they are separated by mass-to-charge ratio $(\mathrm{m} / \mathrm{z})$. After correction for ambient gases such as $\mathrm{N}_{2}$, mass spectra are analyzed for each 2-min averaged sample, and the sum of organic aerosol peaks is used to calculate total OM. AMS data were processed and analyzed using the standard AMS analysis software, Squirrel version 1.48, implemented with Wavemetric's Igor Pro (version 6.12). Concentration and uncertainty data for PMF were regenerated using Squirrel v 1.51. Uncertainty 


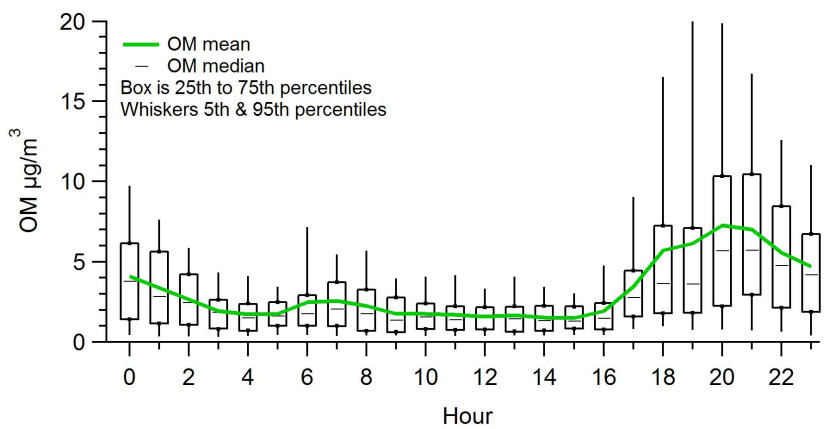

(a)

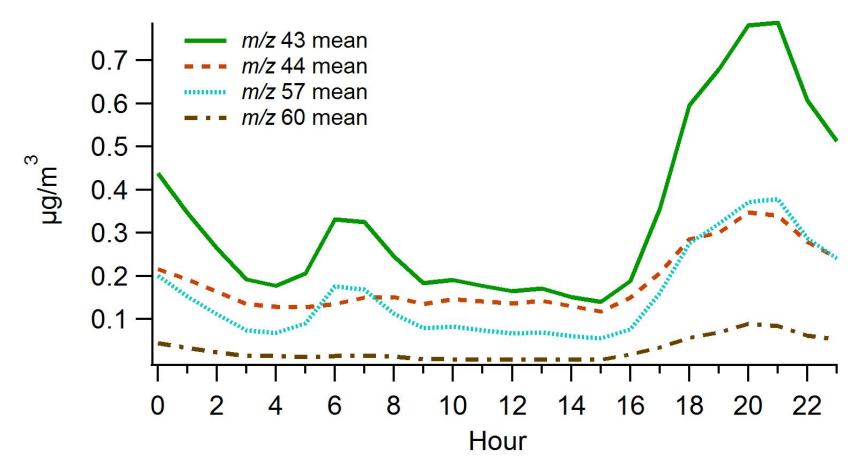

(b)

Fig. 2. (a) Box plot of AMS OM $\left(\mu \mathrm{g} \mathrm{m}^{-3}\right)$ by hour, and (b) average concentrations $\left(\mu \mathrm{g} \mathrm{m}^{-3}\right)$ of selected $\mathrm{m} / z(43,44,57$, and 60$)$ by hour.

estimates are based on counting statistics methods and generated from Squirrel (Allan et al., 2003b). For a given AMS signal, the error estimate is:

$S(j) \equiv \alpha \sqrt{\frac{\left[I\left(j_{o}\right)+I\left(j_{b}\right)\right]}{t(s)}}$

where the ion signal is $j$, the signal when the beam is open is $\left(I\left(j_{o}\right)\right)$, and the signal when it is blocked is $\left(I\left(j_{b}\right)\right)$ over the sampling time $t(s)$, with a distribution factor $\alpha$.

\subsection{Positive Matrix Factorization}

PMF is a multivariate factor analysis tool (Paatero and Hopke 2009; Paatero, 1997; Paatero and Tapper, 1994, 1993) that has been applied to a wide range of data, including 24-hr speciated $\mathrm{PM}_{2.5}$ data, size-resolved aerosol data, deposition data, air toxics data, volatile organic compound (VOC) data (Kim et al., 2003; Kim and Hopke, 2004; Kim et al., 2004a; Polissar et al., 2001; Poirot et al., 2001; Brown and Hafner, 2003; Hopke, 2003), and more recently to AMS data sets (Lanz et al., 2008a; Docherty et al., 2008; Ulbrich et al., 2009a). PMF decomposes a matrix of ambient data into two matrices, which an analyst then interprets to identify the represented source types. The method is described in greater detail elsewhere (Paatero, 1997; Paatero and Tapper, 1994). Ulbrich et al., and others (Lanz et al., 2008a, 2007) have also expanded on the details of PMF application to AMS data, including a PMF analysis package in Igor Pro (Ulbrich et al., 2009a). An ambient data set can be viewed as a data matrix $\mathrm{X}$, in which rows (denoted by $i$ ) correspond to samples and columns (denoted by $j$ ) corresponding to chemical species or, in the case of AMS data, to fragments of different $\mathrm{m} / \mathrm{z}$. The goal is to reduce the data set to a small number of factors that best characterize the OM composition with a profile $f$ of each factor and a contribution $g$ for each factor to each sample, plus residuals $e$.

EPA PMF, a freely available data analysis software package that utilizes the multilinear engine (ME-2) to solve the PMF equations described above, was used in this application (Norris et al., 2008, 2009). New features within EPA PMF $\mathrm{v} 4.0$ allow the user to take advantage of rotational tools available in ME-2 (Paatero, 2004). In general, the non-negativity constraint alone in PMF analysis is not always sufficient to produce a unique solution. To reduce the number of solutions, additional information such as known source contributions and/or source compositions can be used. This additional information can be incorporated into the PMF solution by "pulling" parts of a PMF solution, such as a factor profile or contribution. For example, if a source type has a typical ratio among elements in its source profile, a PMFresolved factor profile could be pulled toward that ratio if the user has good confidence that the factor is related to such a source. The strength of each pull is controlled by specifying a limit on the change in the goodness-of-fit parameter $Q$, $d Q$. If the user wishes to perform a weak pull, a small limit on $d Q$ would be allowed. For a stronger pull, a large limit $d Q$ would be allowed. These pulls are activated in ME-2 by the use of an optional control file called "moreparams.txt", which is generated by EPA PMF when a user specifies a pull, or can be generated as a text file by a user outside of EPA PMF and ME-2. When the moreparams file is present, ME-2 generates a solution where the base solution is pulled as indicated in the moreparams file. Additional details are available in Paatero (2004) and Norris et al. (2009).

\subsection{AMS data for EPA PMF application}

A matrix of 7455 2-min HR-AMS V-mode observations of 198 unit mass resolution (UMR) fragments made every $4 \mathrm{~min}$ during January 2008 at Fyfe was used in EPA PMF analysis. Fragments predominantly from inorganic species such as nitrate and sulfate were not retained for EPA PMF analysis. Fragments $m / z 15,18,19,20,29$, and 30 were excluded from EPA PMF analysis because of potential interference with nitrogen and oxygen. While data up to $m / z 700$ are available, many fragments above $m / z 200$ had low signal-tonoise $(\mathrm{S} / \mathrm{N})$ ratios (i.e., less than 6$)$, made a minimal contribution to total OM, and were collinear with a number of other fragments. Fragments up to $m / z 240$ were retained for EPA PMF, a total of 198 fragments. Fragments with low S/N may bias the results (Norris et al., 2008), so the uncertainties of a 
given fragment were multiplied by 3 if the $\mathrm{S} / \mathrm{N}$ for the fragment was less than 6 ; this reduces the fragment's influence on the solution. A global $10 \%$ uncertainty was also applied to account for additional modeling uncertainty (Norris et al., 2008). EPA PMF was run in the robust mode, which reduces the influence of outliers.

Each observation was also classified as downwind (wind speed greater than $2 \mathrm{~m} \mathrm{~s}^{-1}$ and wind direction between 90 and 270 degrees; $N=1360$ ); upwind (wind speed greater than $2 \mathrm{~m} \mathrm{~s}^{-1}$ and wind direction between 310 and 60 degrees; $N=949$ ); other (wind speed greater than $2 \mathrm{~m} \mathrm{~s}^{-1}$ and wind direction between 60 and 90 degrees or between 270 and 310 degrees; $N=461$ ); or calm (wind speed less than $2 \mathrm{~m} \mathrm{~s}^{-1} ; N=4907$ ). As an additional set of runs, EPA PMF was also applied to downwind-only data to examine whether factor profiles change, and how factor contributions change. Since downwind-only data are more heavily influenced by the freeway, we may expect that a downwind-only HOA factor would be more similar to vehicle exhaust source profiles than when all data are used.

The AMS PMF results were averaged up to 20-min intervals to allow for matching with the collocated 5-min data, which were also averaged up to 20-min intervals. The 20min averaged AMS data $(N=1491)$ were also re-analyzed with EPA PMF to evaluate the impact of high-mass transient events; profiles and contributions were then compared to the results using 2-min data. Factor profiles were compared to PMF factor profiles from earlier ambient studies (Lanz et al., 2008a, 2007; Ulbrich et al., 2009a) as well as to source profiles (Mohr et al., 2009; Sage et al., 2008; Weimer et al., 2008) originating from a publicly available online database of reference spectra hosted by University of Colorado (Ulbrich et al., 2009a, 2009b). Specifically, source profiles of Honda gasoline exhaust and diesel exhaust (Mohr et al., 2009), PMF-resolved OOA and HOA factor profiles from Pittsburgh (Zhang et al., 2005a), BBOA factor profiles from Switzerland (Lanz et al., 2007, 2008b), aged diesel exhaust profile from chamber experiments (Sage et al., 2008), and burning and smoldering oak and chestnut wood source profiles (Weimer et al., 2008) were used.

\section{Results}

\subsection{Ambient aerosol variability and composition}

OM averaged $3.3 \mu \mathrm{g} \mathrm{m}^{-3}$ during the January intensive campaign and was typically highest during the evening hours (i.e., 19:00 through 21:00 LST) with a secondary peak in the morning (i.e., 06:00-09:00 LST, during rush hour commute) as shown in Fig. 2. AMS fragments associated with HOA, such as $m / z 57$ and $m / z$ 43, showed a similar diurnal pattern. AMS fragments associated with OOA, such as $m / z 44$ $\left(\mathrm{COO}^{+}\right)$, showed only minor fluctuations throughout the day, while those used as tracers of biomass burning, such as $\mathrm{m} / \mathrm{z}$
60 (Lanz et al., 2007, 2008b), were evident only during the evening and overnight hours.

Concentrations of other species such as $\mathrm{BC}, \mathrm{CO}$, and $\mathrm{NO}_{\mathrm{x}}$ showed peaks in the early morning and overnight. There was only modest correlation (i.e., $r^{2}$ of 0.40 to 0.60 ) of $\mathrm{OM}$ and fragments such as $m / z 43,44,57$, and 60 with $\mathrm{BC}, \mathrm{CO}$, and $\mathrm{NO}_{\mathrm{x}}$. Since $\mathrm{BC}$ and $\mathrm{CO}$ are from primary emissions and $\mathrm{OM}$ is a mixture of primary emissions and secondary products of atmospheric reactions, the modest correlations among these parameters suggest that a large fraction of the $\mathrm{OM}$ may be secondary in nature. OM concentrations were similar between upwind and downwind conditions (medians of $2.0 \mu \mathrm{g} \mathrm{m}^{-3}$ and $1.6 \mu \mathrm{g} \mathrm{m}^{-3}$, respectively); there was a higher median $\mathrm{OM}$ concentration during upwind conditions since these occurred during the evening, when wind speeds were lower and the boundary layer shallower than during the daytime, when downwind conditions prevailed and higher wind speeds and more dispersion occurred. In contrast, other pollutants showed sharper differences between upwind and downwind conditions; for example, concentrations of primary emission pollutants such as BC were more than three times higher under downwind conditions than under upwind conditions (Roberts et al., 2010). Rather than being highest during downwind conditions, OM was highest during stagnant, low-wind conditions, with an average of $3.7 \mu \mathrm{g} \mathrm{m}^{-3}$.

While OM did have a distinctive diurnal pattern in general, it was episodic during the intensive. A multi-day OM episode occurred with relatively high, sustained concentrations in the first week (Fig. 3). The episode ended around midnight on 12 January when a storm front came through the area. During the episode, OM concentrations were relatively high during the overnight periods under a stable boundary layer. A short-duration but very high OM concentration episode occurred the evening of 19 January, with the highest 2-min and hourly averaged OM concentrations of the entire intensive. Although sampling took place over four weekends, the meteorological conditions during those weekends were quite different, with drizzle and rain on the first weekend (Sunday, 6 January), a front with high winds and rain on the second (Saturday night 12 January), a stagnation episode on the third (Saturday 19 January), and windy conditions on the last weekend. With the low number of weekends and the wide range of meteorological conditions, comparing weekday to weekend concentrations may not be as useful here compared to data sets that comprise many weekends.

$\mathrm{OM}$ concentrations were generally similar whether our monitoring site was upwind or downwind of the freeway (Fig. 4). This is different than for other pollutants such as $\mathrm{BC}$, where downwind concentrations were, on average, more than two times higher during downwind conditions. This shows that the enhancement of being next to the roadway is not nearly as large for $\mathrm{OM}$ as for $\mathrm{BC}$, since $\mathrm{OM}$ is a mixture of primary, semi-volatile, and more oxidized material, whereas BC is primary material that, in a near-roadway environment, predominantly originates from emissions along 


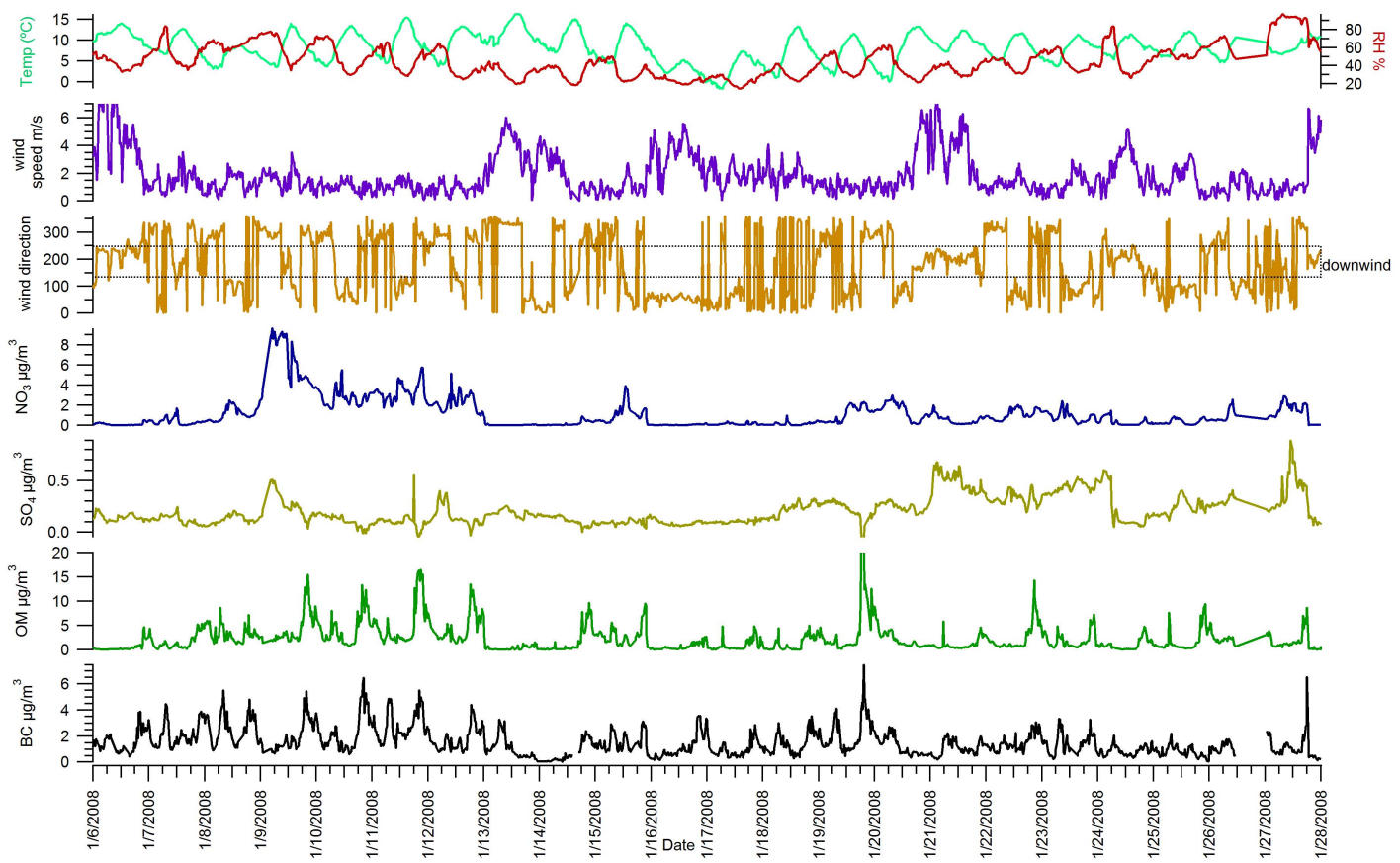

Fig. 3. Time series of temperature (degrees C), relative humidity (\%), wind speed $\left(\mathrm{m} \mathrm{s}^{-1}\right)$, wind direction, AMS nitrate $\left(\mu \mathrm{g} / \mathrm{m}^{3}\right), \mathrm{AMS}$ sulfate $\left(\mu \mathrm{g} \mathrm{m}^{-3}\right)$, AMS OM $\left(\mu \mathrm{g} \mathrm{m}^{-3}\right)$, and Aethalometer BC $\left(\mu \mathrm{g} \mathrm{m}^{-3}\right)$. Major tick marks indicate midnight for each day. Periods during which the monitoring site is downwind of the freeway are indicated by the dashed rectangle on the wind direction time series.

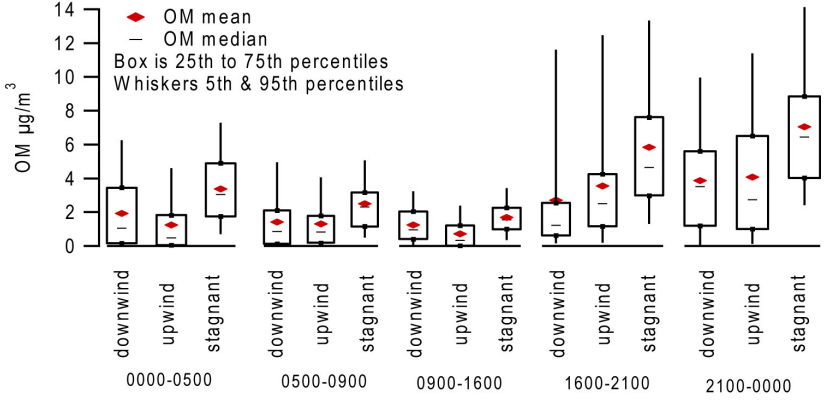

Fig. 4. Box plot of OM concentrations $\left(\mu \mathrm{g} \mathrm{m}^{-3}\right)$ during downwind, upwind and stagnant (wind speed less than $0.5 \mathrm{~m} \mathrm{~s}^{-1}$ ) conditions, grouped by time of day.

the roadway. Like BC, OM was higher during stagnant conditions (those with winds less than $0.5 \mathrm{~m} \mathrm{~s}^{-1}$ ), as a shallow boundary layer and minimal dispersion quickly led to the buildup of pollutants. During the daytime when emissions from the freeway may be most prominent, concentrations during downwind conditions were higher than during upwind conditions. Only during the evening hours (17:0023:00 LST), when non-mobile emission sources become important, were upwind concentrations higher than downwind. This increase is likely due to contributions from residential biomass burning, as explored further with PMF.
Temporal patterns for both sulfate and nitrate differed from the temporal pattern for OM. Sulfate concentrations were extremely low throughout the study, with a median concentration of $0.16 \mu \mathrm{g} \mathrm{m}^{-3}$, and a maximum 20-min average of $0.88 \mu \mathrm{g} \mathrm{m}^{-3}$. Nitrate concentrations were episodic but were also typically low, with a median concentration of $0.54 \mu \mathrm{g} \mathrm{m}^{-3}$. Nitrate had little relationship with OM or other measured pollutants. In a one-day episode, nitrate peaked above $8 \mu \mathrm{g} \mathrm{m}^{-3}$ for three hours, after which it decreased to approximately $2 \mu \mathrm{g} \mathrm{m}^{-3}$ for the next two days. This episode occurred after a 24-h period when winds were stagnant, temperatures were low (less than $8^{\circ} \mathrm{C}$ ), and relative humidity was relatively high (greater than $55 \%$ ), including during the midday, which was atypical. Nitrate was greater than $1 \mu \mathrm{g} \mathrm{m}^{-3}$ on a few other days, but these periods typically lasted only a few hours. These higher concentrations occurred during the day and night, with no distinct, consistent diurnal pattern, unlike $\mathrm{OM}, \mathrm{BC}, \mathrm{CO}$, and other pollutants, which peaked in the evening and early morning hours. In contrast to the inorganic species, BC had a median concentration of $1.24 \mu \mathrm{g} \mathrm{m}^{-3}$, more than twice as high as nitrate, an order of magnitude higher than sulfate, and a third of OM. $\mathrm{BC}$ is more than twice as high at this site compared to a site $2 \mathrm{~km}$ away in the urban center but away from freeways (Hancock Elementary School), where BC was, on average, $0.5 \mu \mathrm{g} \mathrm{m}^{-3}$.

These sulfate levels are quite low compared to most other areas in the US, though typical of the western US, as there 
is minimal transport of sulfate into Las Vegas and no major sources of $\mathrm{SO}_{2}$ or sulfate upwind of the urban area. The nitrate concentrations are also lower than is typical in western urban areas. There have been limited studies of speciated $\mathrm{PM}_{2.5}$ in Las Vegas, with the 2000-2001 Las Vegas Valley Visibility/PM 2.5 study the most detailed and recent. Here they found wintertime sulfate concentrations, on average, lower than $0.5 \mu \mathrm{g} \mathrm{m}^{-3}$, and average nitrate concentrations between 0.2 and $0.6 \mu \mathrm{g} \mathrm{m}^{-3}$ at three sites (Green et al., 2002). There are very few sources upwind, so the amount of transported secondary organic carbon and ammonium sulfate is generally low, though there can be transport from California. Some speciated $\mathrm{PM}_{2.5}$ data have been collected as part of EPA's chemical speciation network (CSN) from 2002 to 2007. Using the data from this 5 -yr period, average sulfate concentrations are $1 \mu \mathrm{g} \mathrm{m}^{-3}$, and average nitrate concentrations are $0.89 \mu \mathrm{g} \mathrm{m}^{-3}$, though sulfate is lower and nitrate is higher in the winter. These low values are corroborated by Chapter 2 of the IMPROVE network annual report (Hand et al., 2011), which shows that sulfate and nitrate concentrations are extremely low in Las Vegas compared to other areas in the US and are lower than $1 \mu \mathrm{g} \mathrm{m}^{-3}$, on average. Unlike most of the US or much of Europe, there is very little coal-fired power production upwind of Las Vegas, so $\mathrm{SO}_{2}$ (and sulfate) levels are low. In many prior studies elsewhere, sulfate concentrations are higher and are correlated with LVOOA concentrations; however, as the sulfate levels are so low in Las Vegas, it is unlikely that LV-OOA will correlate with sulfate. As Las Vegas is in an arid desert environment with little agriculture in the area, ammonia emissions are relatively low (e.g., http://nadp.sws.uiuc.edu/nh3net/), so ammonium nitrate formation may be limited by the availability of ammonia. Nitrate has been observed to often correlate with SV-OOA, as both may be associated with similar transport and formation mechanisms. When nitrate formation is limited by ammonia availability, however, there is little reason to expect it to correlate with SV-OOA.

\subsection{EPA PMF application to AMS data summary}

Three- to six-factor solutions were explored with EPA PMF. Initially, 50 runs from a random seed were performed for each number of factors. Random starting seeds were used to increase the likelihood of finding a global minimum of the goodness-of-fit parameter, $Q$. The stability of $Q$ over these runs, the ratio of $Q$ to expected (theoretical) $Q$, scaled residuals, the $Q / Q_{\text {expected }}$ by fragment and sample, and factor independence (G-space plots) were examined. If these parameters are not stable for a given number of factors, it indicates that a global minimum was not consistently achieved, and that a solution may not be stable (Norris et al., 2009, 2008). In all solutions, the total OM was well apportioned (i.e., slope equal to $1.0 \pm 0.10$ ) and $r^{2}$ was greater than 0.95 between apportioned and total OM.

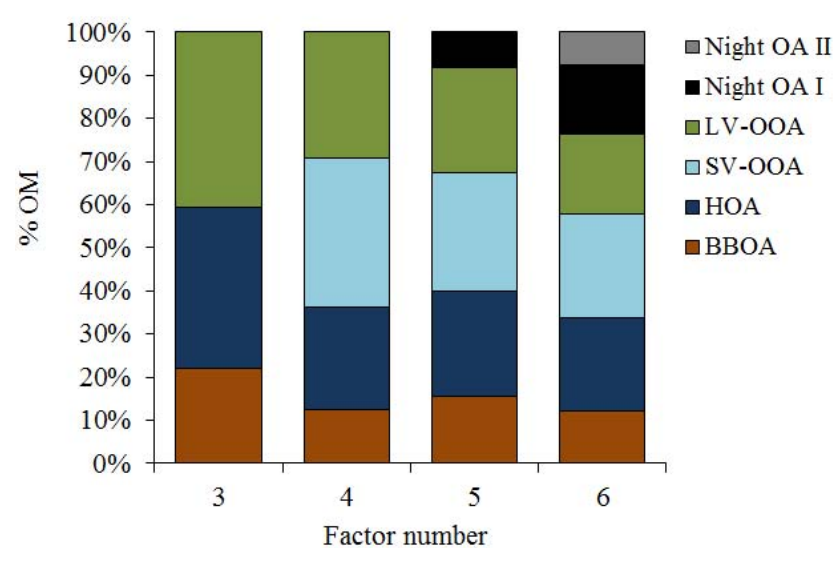

Fig. 5. Summary of OM apportioned by factor number.

PMF factors were classified by their temporal pattern and the comparison of their profile with source profiles and profiles from previous studies. The typical AMS PMF factors of HOA, LV-OOA, and BBOA were resolved in every solution with three or more factors, and the identification of each factor profile was based on its similarity to profiles available in the literature, the abundance of key fragments in each profile, and each factor's temporal pattern. For example, the LV-OOA factors displayed a significant amount of $\mathrm{m} / \mathrm{z} 44$ and were similar to the OOA factor identified in Pittsburgh and elsewhere. BBOA factors had typical tracer fragments of $m / z 60$ and 73, which are produced during AMS analysis of levoglucosan and related anhydrosugars produced during biomass combustion (Lanz et al., 2008b, 2010; Alfarra et al., 2004). The HOA factors were similar to the HOA factor from Pittsburgh and a diesel exhaust source profile.

With more than three factors, semi-volatile OOA (SVOOA) was also resolved. This factor's profile was similar to that of aged diesel exhaust and was more episodic than HOA or LV-OOA profiles. With five and six factors, additional factors that occurred during the nighttime were resolved. The additional nighttime factors occurred nearly every night coincident with BBOA between 17:00 and 02:00 LST, and contributions were higher with low wind speed conditions and with winds from the north (upwind). With peaks of $m / z 41$, 43,55 , and 91, it is unclear what these "night OA" factors may represent. The change in the BBOA between the fourand five-factor solutions and its temporal variability suggest the additional fifth factor may be related to biomass burning, but the lack of known tracer fragments and correlation with source profiles makes this link difficult to prove. We focused the remainder of the analyses on the four-factor solution. Figure 5 summarizes the amount of OM apportioned by factor. Table 1 summarizes the correlation of factor profiles with selected source, aged source, and PMF factor profiles from other studies. 
Table 1. Correlation $\left(r^{2}\right)$ of PMF factor profiles with Pittsburgh ${ }^{1}$ OOA PMF profile, Pittsburgh HOA PMF profile, diesel exhaust source profile $^{2}$, aged diesel exhaust profile ${ }^{3}$, charbroil ${ }^{4}$ source profile, oak-flame ${ }^{5}$ source profile, oak-smolder source profile, chestnut-flame source profile, chestnut-smolder source profile, and levoglucosan ${ }^{6}$ profile. Correlations from 0.80 to 0.90 are denoted in italics, and those greater than 0.90 are denoted in bold.

\begin{tabular}{lllllllllllll}
\hline $\mathrm{N}$ & Factor & $\begin{array}{l}\text { Pitt } \\
\text { HOA }\end{array}$ & $\begin{array}{l}\text { gas- } \\
\text { oline }\end{array}$ & $\begin{array}{l}\text { Diesel } \\
\text { OOA }\end{array}$ & $\begin{array}{l}\text { Pitt } \\
\text { diesel }\end{array}$ & $\begin{array}{l}\text { Aged } \\
\text { charbroil } \\
\text { smolder }\end{array}$ & $\begin{array}{l}\text { Oak } \\
\text { flame }\end{array}$ & $\begin{array}{l}\text { Oak } \\
\text { glucosan }\end{array}$ & $\begin{array}{l}\text { levo- } \\
\text { flame }\end{array}$ & $\begin{array}{l}\text { Chestnut } \\
\text { smolder }\end{array}$ & Chestnut \\
\hline 3 & LV-OOA & 0.59 & 0.58 & 0.58 & $\mathbf{0 . 9 8}$ & $\mathbf{0 . 9 5}$ & 0.26 & 0.88 & $\mathbf{0 . 9 1}$ & 0.74 & 0.83 & 0.89 \\
& HOA & $\mathbf{0 . 9 7}$ & $\mathbf{0 . 9 2}$ & $\mathbf{0 . 9 5}$ & 0.46 & 0.75 & 0.57 & 0.29 & 0.71 & 0.49 & 0.50 & 0.62 \\
& BBOA & 0.80 & 0.73 & 0.76 & 0.67 & 0.82 & 0.40 & 0.44 & 0.89 & 0.77 & 0.77 & 0.85 \\
4 & LV-OOA & 0.38 & 0.39 & 0.38 & $\mathbf{0 . 9 9}$ & 0.87 & 0.13 & $\mathbf{0 . 9 3}$ & 0.83 & 0.70 & 0.80 & 0.84 \\
& HOA & $\mathbf{0 . 9 9}$ & $\mathbf{0 . 9 6}$ & $\mathbf{0 . 9 8}$ & 0.48 & 0.77 & 0.60 & 0.32 & 0.69 & 0.48 & 0.50 & 0.62 \\
& BBOA & 0.47 & 0.41 & 0.44 & 0.59 & 0.64 & 0.20 & 0.39 & 0.75 & 0.80 & 0.77 & 0.80 \\
SV-OOA & $\mathbf{0 . 9 1}$ & 0.84 & 0.87 & 0.57 & 0.79 & 0.49 & 0.37 & 0.80 & 0.58 & 0.60 & 0.71 \\
5 & LV-OOA & 0.46 & 0.46 & 0.46 & $\mathbf{0 . 9 9}$ & $\mathbf{0 . 9 0}$ & 0.18 & $\mathbf{0 . 9 1}$ & 0.88 & 0.72 & 0.82 & 0.87 \\
& HOA & $\mathbf{0 . 9 9}$ & $\mathbf{0 . 9 7}$ & $\mathbf{0 . 9 8}$ & 0.47 & 0.78 & 0.61 & 0.32 & 0.68 & 0.49 & 0.50 & 0.62 \\
& BBOA & 0.71 & 0.69 & 0.69 & 0.86 & $\mathbf{0 . 9 1}$ & 0.37 & 0.69 & $\mathbf{0 . 9 5}$ & 0.89 & $\mathbf{0 . 9 1}$ & $\mathbf{0 . 9 7}$ \\
& SV-OOA & 0.90 & 0.82 & 0.85 & 0.56 & 0.78 & 0.47 & 0.37 & 0.79 & 0.56 & 0.58 & 0.69 \\
& Night OA I & 0.60 & 0.51 & 0.59 & 0.42 & 0.61 & 0.27 & 0.26 & 0.57 & 0.30 & 0.35 & 0.45 \\
6V-OOA & 0.13 & 0.16 & 0.15 & 0.59 & 0.46 & 0.05 & 0.54 & 0.47 & 0.44 & 0.51 & 0.51 \\
& HOA & 0.12 & 0.17 & 0.14 & 0.55 & 0.38 & 0.11 & 0.60 & 0.42 & 0.43 & 0.49 & 0.48 \\
BBOA & 0.24 & 0.26 & 0.24 & 0.72 & 0.57 & 0.13 & 0.66 & 0.59 & 0.56 & 0.63 & 0.64 \\
& SV-OOA & 0.24 & 0.28 & 0.25 & 0.61 & 0.48 & 0.12 & 0.60 & 0.54 & 0.54 & 0.59 & 0.61 \\
Night OA I & 0.33 & 0.36 & 0.34 & 0.54 & 0.48 & 0.16 & 0.47 & 0.53 & 0.55 & 0.56 & 0.61 \\
Night OA II & 0.14 & 0.16 & 0.15 & 0.49 & 0.35 & 0.03 & 0.47 & 0.42 & 0.42 & 0.44 & 0.47 \\
\hline
\end{tabular}

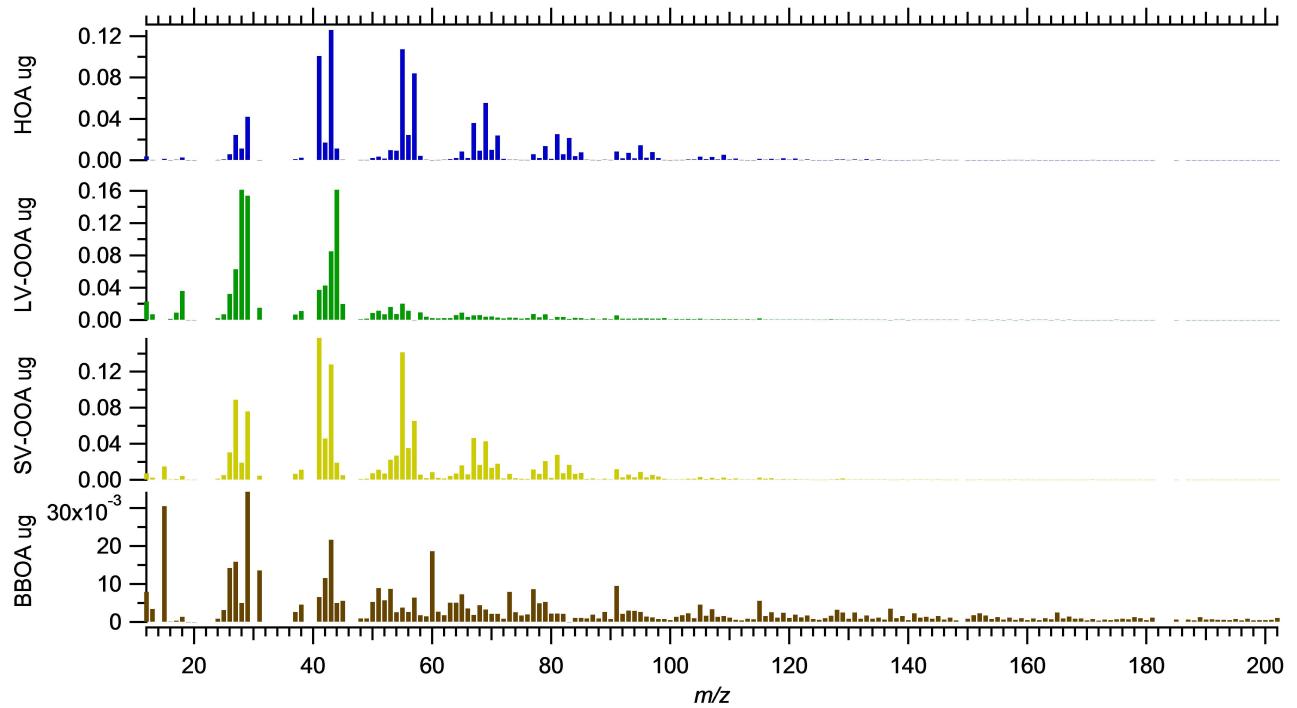

Fig. 6. PMF factor profiles through $m / z 200$ for the four-factor solution.

\subsection{Four-factor solution}

The factors in the four-factor solution were HOA, LV-OOA, and BBOA factors, plus a semi-volatile OOA (SV-OOA) factor. The HOA and LV-OOA factors were better resolved than in the three-factor solution. Profiles of each factor, the average factor concentration plus other species' concentra- tions by hour, and a time series of concentrations are provided in Figs. 6 through 8. Figure 9 provides scatter plots of factor contributions with selected collocated measurements: HOA with BC, HOA with CO, SV-OOA with nitrate, and LVOOA with sulfate. Factor profiles were compared to profiles available in the literature to help confirm identification; regression statistics were reported using Pearson correlation 


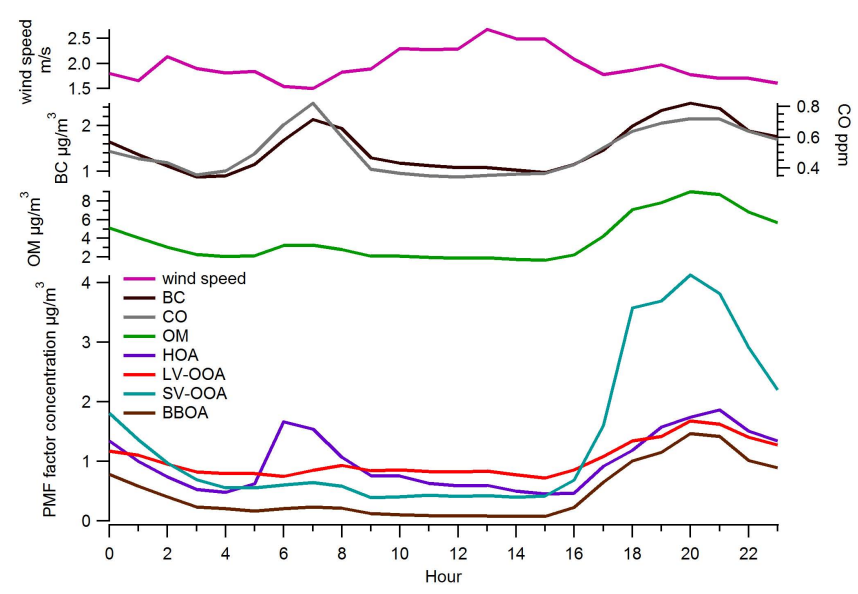

Fig. 7. $\mathrm{PMF}$ factor contributions, $\mathrm{OM}, \mathrm{BC}, \mathrm{CO}$, and wind speed averaged by hour.

values, and each scatter plot associated with the regression statistics was examined to ensure that the correlation was not biased by the large range of concentrations of the individual $m / z$ fragments. Bootstrapping, in which many runs are used to gauge the uncertainty of the base solution (in this case 300 runs with an $r^{2}$ of 0.60 ), showed good reproducibility of the factors. All factors were reproduced at least $98 \%$ of the time, demonstrating that these factors are stable and characterize the solution space well.

The LV-OOA factor displayed the typical high amount of $\mathrm{m} / \mathrm{z} 44$ but with a lower amount of $\mathrm{m} / \mathrm{z} 43$ than in the threefactor solution, and it showed a high correlation with the Pittsburgh OOA factor profile ( $r^{2}$ of 0.99; Table 1). LV-OOA accounted for $26 \%$ of the OM with four factors and showed only small diurnal variability in its concentration, though it was a much greater percentage of the OM during the daytime than at other times. Similar to other factors and total OM, LV-OOA concentrations were lower at higher wind speeds, though it was a higher percentage of OM at higher wind speeds. LV-OOA showed little correlation with other pollutants; ozone, which often showed a moderate correlation with LV-OOA in other studies, was not measured here. Sulfate is also often correlated with LV-OOA, but during this study sulfate levels were extremely low, with a median of $0.16 \mu \mathrm{g} \mathrm{m}^{-3}$. LV-OOA is heavily oxidized and likely part of a background $\mathrm{OM}$, and it may be transported into Las Vegas over multiple days. In addition, there are very few $\mathrm{SO}_{2}$ sources upwind of Las Vegas, so there is very little sulfate transported into the area. Thus, we may not expect LV-OOA concentrations to be correlated with sulfate here.

The BBOA factor accounted for $12 \%$ of OM, on average, and was similar to the BBOA factor found in the three-factor solution. This factor had more than $60 \%$ of the $\mathrm{m} / z 60 \mathrm{frag}$ ment, which is associated with levoglucosan and related anhydrosugars (Lanz et al., 2008b; Alfarra et al., 2004); the contribution from BBOA was well correlated with $\mathrm{m} / \mathrm{z} 60$ $\left(r^{2}=0.86\right)$. This factor is most likely from residential wood burning in the evenings rather than wildfire emissions since there was little regional wildfire activity in the winter; furthermore, the contribution was nearly zero during the daytime, with a sharp rise in concentrations nearly every evening after 17:00 LST that peaked around 21:00 LST. While the BBOA factor concentration began to decrease after around 21:00 LST, its relative contribution to OM remained above $15 \%$ until after midnight. The factor was highest in terms of both concentration and relative contribution to $\mathrm{OM}$ under low wind speed conditions (i.e., less than $2 \mathrm{~m} \mathrm{~s}^{-1}$ ). This profile is similar to a smoldering Chestnut profile $\left(r^{2}=0.80\right)$ and the levoglucosan combustion profile $\left(r^{2}=0.80\right)$ (Schneider et al., 2006). This BBOA factor is mostly associated with winds from the north and west-the direction of a large residential neighborhood upwind of the freeway. When using five factors, the BBOA factor profile has even better correlations with both of these profiles $\left(r^{2}\right.$ of 0.89 and 0.91$)$, plus an $r^{2}$ of 0.95 with an oak flaming profile. However, since the fifth factor is unidentified, we have focused on the four-factor solution.

The HOA factor accounted for $26 \%$ of the OM and had peaks of $m / z 41,43,55,57$, and other fragments typical of hydrocarbon-like fragments. HOA concentrations were highest during the early morning and overnight periods, and as a percent of total OM, the factor's contributions were highest during the early morning (06:00-08:00 LST). The HOA factor profile has a high correlation with diesel exhaust $\left(r^{2}=0.98\right)$ and gasoline exhaust $\left(r^{2}=0.96\right)$ source profiles (Mohr et al., 2009). The HOA profile here was very similar to that observed in Pittsburgh $\left(r^{2}=0.99\right)$. This factor is likely heavily influenced by the mobile emissions on the adjacent freeway but may also have originated in part from other sources. Similar to concentrations of BBOA and other pollutants such as $\mathrm{BC}, \mathrm{HOA}$ concentrations rapidly decreased with increases in wind speed, though on a relative basis there was no significant difference in its contribution. With sustained winds (i.e., greater than $2 \mathrm{~m} \mathrm{~s}^{-1}$ ), HOA concentrations were significantly higher under downwind conditions. HOA had modest correlation with collocated measurements of $\mathrm{CO}\left(r^{2}=0.66\right), \mathrm{NO}_{\mathrm{x}}\left(r^{2}=0.64\right)$, and $\mathrm{BC}\left(r^{2}=0.68\right)$. This may be in part because $\mathrm{BC}, \mathrm{CO}$, and $\mathrm{NO}_{\mathrm{x}}$ have large differences between upwind and downwind conditions. For example, during November - March, BC is twice as high under downwind conditions (average $2.3 \mu \mathrm{g} \mathrm{m}^{-3}$ ) than upwind conditions (average $1.2 \mu \mathrm{g} \mathrm{m}^{-3}$ ), while OM (and HOA) do not have as large a difference.

The last factor resolved was semi-volatile OOA (SVOOA), which accounted for $35 \%$ of the OM. It showed strong peaks of $m / z 41,43,55,57,67,69$, and 71 but also had some contribution from $m / z 44$, with a $43 / 44$ ratio of 6 , almost half the value for HOA (11). The SV-OOA factor profile had a moderate correlation with Pittsburgh HOA and with chamber-aged diesel exhaust ( $r^{2}$ of 0.91 and 0.79 , respectively). SV-OOA contributions were highest in the evening 


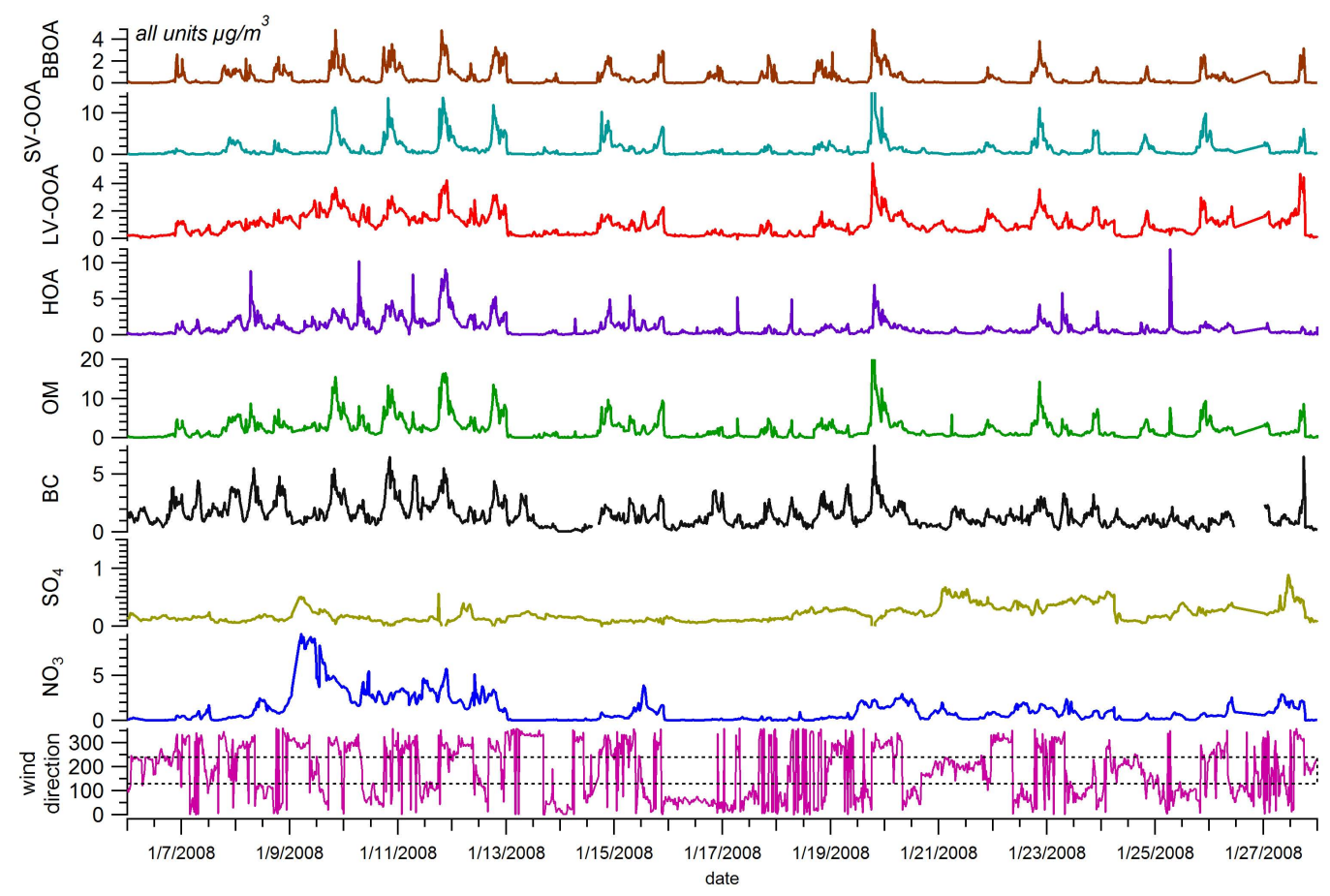

Fig. 8. Time series of PMF factor contributions, BC, sulfate, nitrate, and OM (all in $\mu \mathrm{g} \mathrm{m}^{-3}$ ), plus wind direction. Times when the monitoring site is downwind are outlined by the dashed box.

and overnight hours, though on a relative basis its contributions were generally very consistent across all hours. Like HOA, SV-OOA factor contributions decreased with higher wind speeds, but its relative contribution was not significantly different among wind speed ranges. In other studies, this factor sometimes has a modest correlation with nitrate. Here, nitrate was extremely episodic, in that its concentrations were less than $0.5 \mu \mathrm{g} \mathrm{m}^{-3}$ half the time, with a day-long episode of concentrations greater than $4 \mu \mathrm{g} \mathrm{m}^{-3}$ and a few hours during which concentrations intermittently exceeded $2 \mu \mathrm{g} \mathrm{m}^{-3}$. In contrast, SV-OOA was present during nearly the entire study and had a modest diurnal pattern similar to other factors where it was highest in evening hours.

It is also possible that the SV-OOA factor contains some contribution from cooking organic aerosol (COA), as the SVOOA factor shows similarities in both profile and temporal patterns to a COA factor found in London and Manchester (Allen et al., 2010). Similar to the COA profile, the largest peaks in the SV-OOA profile are at $m / z 41$ and $m / z 55$, and in both profiles $m / z 41$ is greater than $m / z 43$ and $m / z 55$ is more than twice $m / z 57$; this is in contrast to HOA, where $m / z 43$ is greater than $m / z 41$, and $m / z 55$ is only slightly higher than $m / z$ 57. Similar to the COA factor, our SV-OOA factor peaks, on average, in the evening, again in contrast to HOA, which peaks in the morning and evening hours associated with rush hour. There are, however, times when the SVOOA factor is high that are not likely periods of high cooking emissions, such as late morning or midday. Expanding to five factors was inconclusive, since the fifth factor was similar to SV-OOA and COA but was generally collinear with BBOA; it was unclear what this fifth factor represented, so we have retained the SV-OOA label for this factor, with the caveat that there is likely some COA influence.

To help confirm factor identification and understand the OM composition difference between upwind and downwind conditions, we examined the factor contributions during downwind $(N=1360)$ and upwind $(N=949)$ conditions and compared them to the average over the study period. We also examined the OM composition under downwind conditions $(N=195)$ from 05:00 to 09:00 LST, when the impact from emissions on the freeway is expected to be highest. Results are summarized in Fig. 10. As expected, HOA contributions are higher under downwind conditions; during morning downwind conditions, HOA accounts for $49 \%$ of the OM. SV-OOA was, on average, similar during upwind, downwind, and stagnant conditions, except during morning downwind situations when it was only $23 \%$ of the OM. The minimal difference with different wind directions suggests that SV-OOA is a slightly aged factor that is not characteristic of direct, primary emissions. BBOA contributions were low, on average, under downwind conditions and higher $(16 \%$ on average) during upwind conditions. LV-OOA contributions were relatively lower during morning downwind conditions and relatively highest during midday periods, regardless of wind direction. 
a)

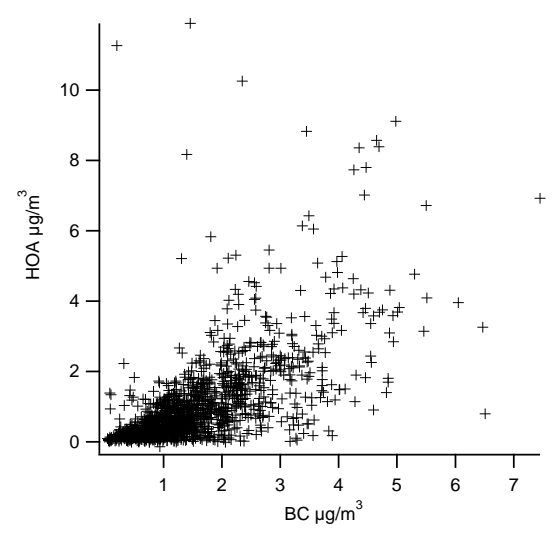

c)

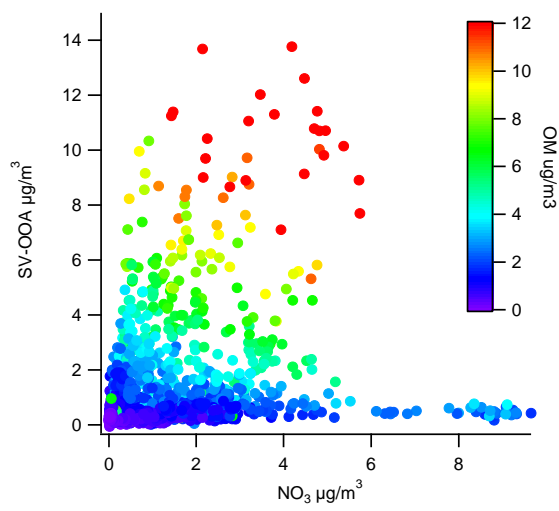

b)

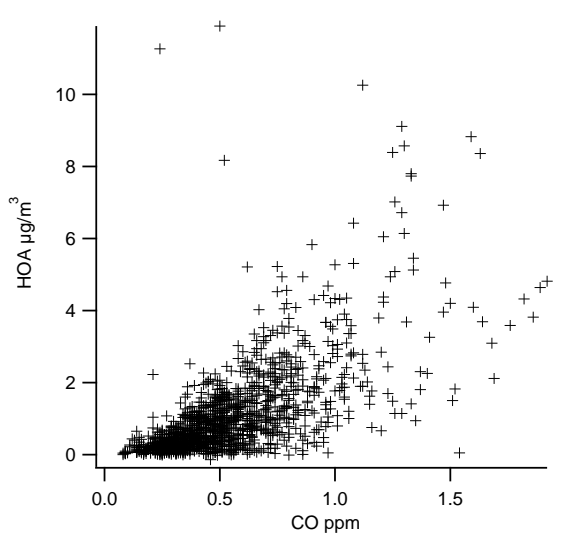

d)

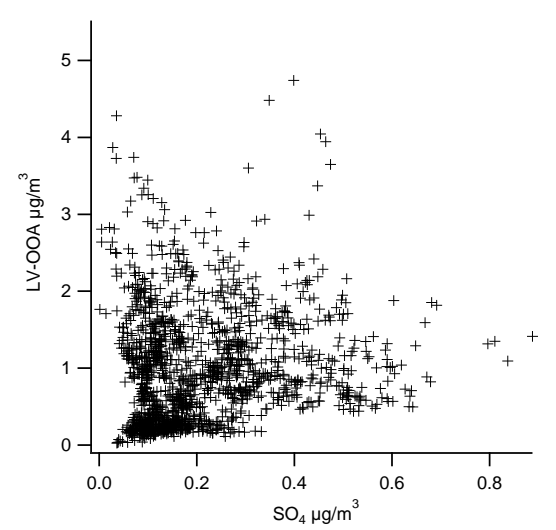

Fig. 9. Scatter plot comparisons of PMF factor contributions for: (a) HOA and BC; (b) HOA and CO; (c) SV-OOA and nitrate; and (d) LV-OOA and sulfate.

\subsection{Further analysis using ME-2 rotational tools in EPA PMF}

$F_{\text {peak }}$ is a parameter available in PMF to rotate the entire solution, a process that can help indicate if there is rotational freedom in the solution. G-space plots of the base solution show distinct edges, indicating some factor interdependence. To ascertain whether the solution changes or whether these edges can be rotated to the y-and x-axes, rotation using $F_{\text {peak }}$ was performed. PMF runs were conducted with $F_{\text {peak }}$ values at increments of 2 between 8 and -8 for a total of eight runs. In general, minimal change was seen in the factor profile, contributions, and G-space plots; $Q$ increased by less than $0.1 \%$ for the runs with the highest $F_{\text {peak }}$ value and by even less under other $F_{\text {peak }}$ values. Since there is little change in the solution with $F_{\text {peak }}$-induced rotations, the base solution appears to be rotationally unique. The oblique edges in the G-space plots may be due to co-dependence among factors, or modeling errors, such as variation in true source profiles during the monitoring campaign.
The four-factor solution was further explored with ME2 rotational tools available in EPA PMF. In each scenario, fragment ratios in factor profiles were pulled toward source profile ratios. In one scenario, the ratio of $m / z 43 / 44$ in the SV-OOA factor (6.75) was pulled toward the $m / z$ 43/44 ratio in the 5-hour aged diesel exhaust profile (1.34). In another scenario, the $m / z 57 / 55$ and $41 / 43$ ratios in HOA (0.78 and $0.80)$ were pulled to the ratios in the diesel exhaust profile (1.03 and 0.69, respectively). The BBOA factor ratio of $m / z$ $60 / 91$ was pulled to the chestnut smolder profile ratio (1.96 to 7.20). Lastly, 157 points along an apparent edge in the SVOOA versus LV-OOA G-space plot were pulled in an attempt to force additional independence between these factors. Seeing how the solutions change, in terms of factor profiles, $d Q$, and G-space plots, can help us understand the stability of the original solutions. Different maximum $d Q$ values were allowed for each combination; $1 \%$ and $3 \%$ of $Q$ (robust) were calculated, and these values were used for the maximum $d Q$ allowed for a given pull. In the G-space pull, each point was allowed a $d Q$ of $0.2 \%$, for a total $d Q$ of $31 \%$. 
Table 2. Summary of pulls on the four-factor solutions, all with a maximum allowed $d Q$ of $1 \%$, except for one iteration with BBOA to Chestnut smolder $(d Q=3 \%)$, and except for the edge points pull, which had a total allowed $d Q$ of $31 \%$, or $0.2 \%$ per point with a total of 157 points.

\begin{tabular}{|c|c|c|c|c|c|}
\hline Pull & $\begin{array}{l}\text { SV-OOA to Aged } \\
\text { Diesel }\end{array}$ & HOA to Diesel & $\begin{array}{l}\text { BBOA to Chestnut } \\
\text { Smolder }(d Q=1 \%)\end{array}$ & $\begin{array}{l}\text { BBOA to Chestnut } \\
\text { Smolder }(d Q=3 \%)\end{array}$ & $\begin{array}{l}\text { Edge points on } \\
\text { SV-OOA vs. LV-OOA }\end{array}$ \\
\hline Target & $\begin{array}{l}\text { Ratio } m / z 43 / 44 \text { from } \\
6.75 \text { to } 1.34\end{array}$ & $\begin{array}{l}\text { Ratio } m / z 57 / 55 \text { from } \\
0.78 \text { to } 1.03 \text { and ratio } \\
m / z 41 / 13 \text { from } 0.80 \text { to } \\
0.69\end{array}$ & $\begin{array}{l}\text { Ratio } m / z 60 / 91 \text { from } \\
1.96 \text { to } 7.20\end{array}$ & $\begin{array}{l}\text { Ratio } m / z 60 / 91 \text { from } \\
1.96 \text { to } 7.20\end{array}$ & $\begin{array}{l}157 \text { points pulled to } \\
\text { axis }\end{array}$ \\
\hline $\begin{array}{l}\text { Change in } \\
\text { target values? }\end{array}$ & Yes & Yes & Yes & Yes & Yes \\
\hline$d Q$ & $0.1 \%$ & $0.5 \%$ & $0.4 \%$ & $1.3 \%$ & $8.8 \%$ \\
\hline $\begin{array}{l}\text { Improved } \\
\text { G-space plot? }\end{array}$ & $\begin{array}{l}\text { Worse LV-OOA vs. } \\
\text { SV-OOA plot }\end{array}$ & No change & No change & No change & $\begin{array}{l}\text { No change but for } \\
\text { forced points }\end{array}$ \\
\hline $\begin{array}{l}\text { LV-OOA } \\
\text { vs. Pittsburgh } \\
\text { OOA }\end{array}$ & $\begin{array}{l}\text { Declined } r^{2} \text { from } 0.99 \\
\text { to } 0.93\end{array}$ & No change & No change & No change & No change \\
\hline HOA vs. Diesel & No change & Slightly better & No change & No change & No change \\
\hline $\begin{array}{l}\text { BBOA vs. } \\
\text { Chestnut } \\
\text { smolder }\end{array}$ & $\begin{array}{l}\text { Slightly better; } \\
\text { excl. } m / z 44\end{array}$ & $\begin{array}{l}\text { Improved } r^{2} \text { from } 0.79 \\
\text { to } 0.87\end{array}$ & $\begin{array}{l}\text { Improved } r^{2} \text { from } 0.79 \\
\text { to } 0.88\end{array}$ & $\begin{array}{l}\text { Improved } r^{2} \text { from } 0.79 \\
\text { to } 0.86\end{array}$ & $\begin{array}{l}\text { Improved } r^{2} \text { from } 0.79 \\
\text { to } 0.93\end{array}$ \\
\hline $\begin{array}{l}\text { SV-OOA } \\
\text { vs. Aged } \\
\text { Diesel }\end{array}$ & $\begin{array}{l}\text { Improved } r^{2} \text { from } 0.62 \\
\text { to } 0.69\end{array}$ & $\begin{array}{l}\text { Slightly worse } r^{2} \text { from } \\
0.62 \text { to } 0.57\end{array}$ & $\begin{array}{l}\text { Worse } r^{2} 0.62 \text { to } 0.56 \text {, } \\
\text { due to } m / z 44=0\end{array}$ & $\begin{array}{l}\text { Worse } r^{2} 0.62 \text { to } 0.56 \text {, } \\
\text { due to } m / z 44=0\end{array}$ & $\begin{array}{l}\text { Improved } r^{2} \text { from } 0.69 \\
\text { to } 0.72\end{array}$ \\
\hline $\begin{array}{l}\text { Other changes } \\
\text { of note }\end{array}$ & $\begin{array}{l}0 m / z 44 \text { in BBOA } \\
\text { factor; unreasonable } \\
\text { result }\end{array}$ & $\begin{array}{l}\text { Large decrease in } m / z \\
44 \text { in SV-OOA, } \\
\text { resulting in } 43 / 44 \text { ratio } \\
\text { of } 21 \text {, higher than HOA } \\
\text { ratio of } 10\end{array}$ & $\begin{array}{l}\text { In } \mathrm{SV}-\mathrm{OOA} m / z 44=0 \\
\text { unreasonable result }\end{array}$ & $\begin{array}{l}\text { In SV-OOA } m / z 44=0 \text {; } \\
\text { in BBOA } m / z 55=0 ; \\
\text { unreasonable result }\end{array}$ & $\begin{array}{l}\mathrm{SV}-\mathrm{OOA} m / z 43 / 44 \\
\text { ratio changed from } \\
4.4 \text { to } 2.9\end{array}$ \\
\hline
\end{tabular}

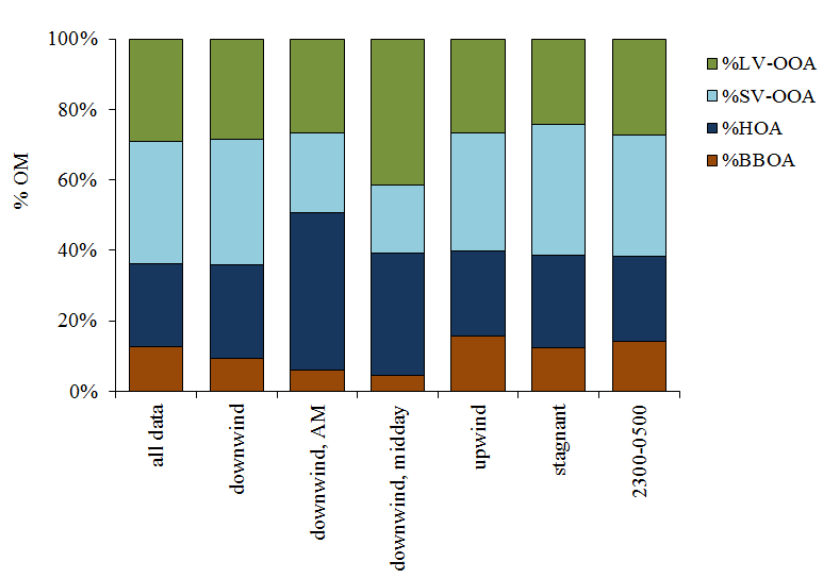

Fig. 10. Attribution of $\mathrm{OM}$ by factor in the four-factor solution over all data, during downwind conditions only, during downwind conditions between 05:00 and 09:00 LST only, during downwind conditions midday, during upwind conditions only, during stagnant conditions, and during 23:00-05:00 LST only.
The results from these pulls are summarized in Table 2 and Fig. 11. Since results were similar with $d Q$ values of $1 \%$ and $3 \%$, only the $d Q$ of $1 \%$ are shown, except for the BBOA pull, where both are provided as an example. In general, most pulls resulted in only minor changes in the HOA and LVOOA factor profiles and contributions. For example, when the HOA factor was pulled toward the diesel exhaust profile, the correlation between the two increased by only 0.02 . In all pulls, the correlation between BBOA and the chestnut smolder profile improved (e.g., correlation improved from 0.79 to 0.88 with the BBOA pull). However this was often at the expense of the SV-OOA profile, where the amount of $m / z$ 44 was much lower compared to the base solution, and in some pulls, was actually zero. While LV-OOA and HOA did not vary much between these pulled solutions, the changes in SV-OOA and BBOA profiles and contributions suggest some rotational freedom in these two factors. LV-OOA and HOA factors are similar across many studies, but the SV-OOA and BBOA factors vary among studies, and within this study under different pulling scenarios, because these factor profiles represent semi-fresh factors that are likely changing minuteto-minute in the atmosphere. Overall, the pulling results 


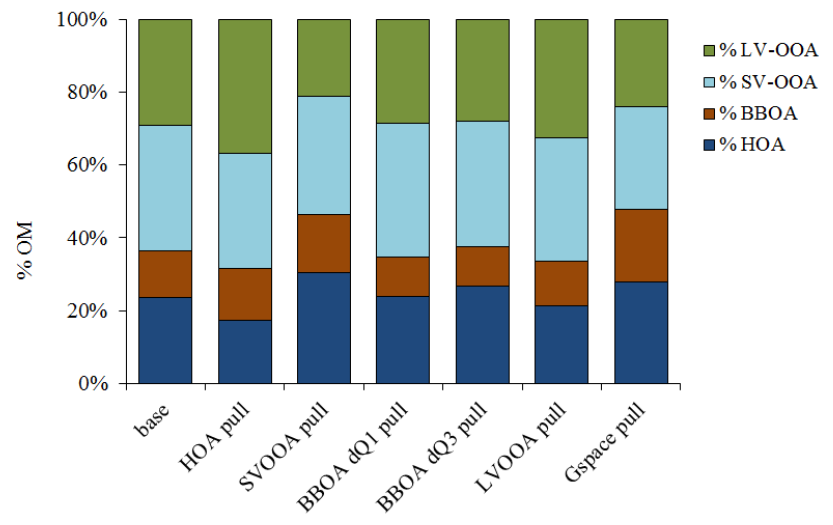

Fig. 11. Attribution of $\mathrm{OM}$ with four factors for base run (base); ratio of $m / z 41 / 43$ in the HOA profile pulled toward the diesel exhaust profile (HOA pull); ratio of $m / z 43 / 44$ in the SV-OOA profile pulled toward the 5-h aged diesel profile (SV-OOA pull); ratio of $m / z 60 / 91$ in the BBOA profile pulled toward the oak-flame source profile with different $d Q$ values (BBOA $d Q 1$ and 3 pull); $m / z 44$ in LV-OOA profile pulled up maximally (LV-OOA pull); and edge points on the HOA/LV-OOA G-space plot pulled down to the $y$ - and $\mathrm{X}$-axes (Gspace pull).

indicate that the base solution is likely at a global $Q_{\text {minima }}$, and that there is little rotational freedom in the unpulled, base solution, in particular regarding the contributions of SVOOA and BBOA.

With the G-space pull, 157 points along an edge in the LVOOA/SV-OOA scatter plot were pulled to reduce LV-OOA to zero. LV-OOA concentrations on these points were successfully reduced towards zero, so that the edge was less well defined. This resulted in a $d Q$ of $9 \%$, but an improvement in the comparison of the BBOA profile to the chestnut smolder profile ( $r^{2}$ from 0.79 to 0.93 ) and in the SV-OOA to aged diesel profile comparison ( $r^{2}$ from 0.69 to 0.72 ). The SV-OOA $m / z$ 43/44 ratio also decreased from 4.4 to 2.9 , which is similar to the ratio of other studies summarized in $\mathrm{Ng}$ et al. (2010). HOA and BBOA contributions increased, while LV-OOA and SV-OOA contributions decreased. Even though $Q$ increased by $9 \%$, these results are useful to show that contribution pulls based on the G-space plots helped improve the factor profiles, and to show what may be the bounds in the base solution results.

\section{Discussion}

Evaluating solutions with different numbers of factors, comparing profiles to source profiles, examining temporal trends, and exploring rotational ambiguity with the rotational tools available in ME-2 can lead to a greater understanding of the AMS data set. In general, all the factors were consistent under multiple scenarios, suggesting high confidence in their apportionment. Increasing the number of factors from four helped to better characterize the solution space, but the additional "night OA" factors are not easily attributable to known sources. Oblique edges were present in G-space plots, suggesting that the obtained rotation may not be the most plausible one. Since solutions found by pulling the profiles or using $F_{\text {peak }}$ retained these oblique edges, there appears to be little rotational freedom in the base solution.

The $Q / Q_{\text {exp }}$ ratios for most fragments were around unity (i.e., between 0.8 and 1.3), indicating that the obtained $Q$ values were approximately equal to the expected values (see Fig. 2 in Supplement for a summary). Some fragments had $Q / Q_{\text {exp }}$ ratios below 0.5 , indicating that computed $Q$ values were significantly smaller than the expected $Q$ values. This discrepancy is most likely due to the global uncertainty ( $\mathrm{s}_{i j}$ increase of $10 \%$ ); since the $Q / Q_{\exp }$ ratios for some $\mathrm{m} / \mathrm{z}$ were fairly low, the $10 \%$ value may be too high for these $m / z$ but appropriate for many other fragments. The $Q / Q_{\exp }$ ratios were between 1.3 and 2 for several $\mathrm{m} / z$, indicating that the average residuals are between 11 and $14 \%$ of $\mathrm{x}_{i j}$ for these $m / z$, since $Q$ depends quadratically on the average size of the residuals. The $Q$ contributions drop sharply beginning at $m / z=198$, as most of these fragments had low $\mathrm{S} / \mathrm{N}$ ratios and were downweighted. The large residuals may indicate that the PMF solution does not fully characterize these fragments ${ }^{7}$. Inaccurate subtraction of the inorganic component from $\mathrm{x}_{i j}$ before PMF analysis is a possibility, though many of the fragments with high $Q / Q_{\exp }$ do not have an inorganic component. More likely, the large residuals are due to the variation of factor profiles with time and/or to the presence of an occasional, spurious, or localized source(s).

While factors in the four-factor solution are similar to those observed elsewhere, the apportionment of mass among them is different from that seen in other studies. This difference is expected because a number of the previous studies occurred in the summer and/or in environments with a higher amount of oxidized aerosol than the present study. Previous studies in Los Angeles, Pittsburgh, rural British Columbia, and elsewhere have typically found that at least one-third of the OM was attributable to LV-OOA, originally termed OOA I (Allan et al., 2003a; Alfarra et al., 2004; Dzepina et al., 2007; Sun et al., 2009). The lower amount of LV-OOA observed during the wintertime Las Vegas study could be due to less transported/aged aerosol, lower biogenic emissions, and/or less overall atmospheric oxidation compared to summertime. In Zurich, a wintertime study found $52 \%$ to $57 \%$ of the OM to be LV-OOA (Lanz et al., 2008a), $69 \%$ of which originated from non-fossil sources such as wood burning. In Las Vegas, there is a much lower concentration of BBOA than in Zurich, leading to a smaller concentration of LV-OOA from non-fossil sources and a smaller concentration of LVOOA overall.

\footnotetext{
${ }^{7}$ Fragments with high $Q / Q_{\exp }$ include $m / z=[44,60,73,85$, $86,111,112,113,114,123,124,125,126,137,138,140,141$, $154,155,156]$.
} 


\section{Conclusions}

EPA PMF v4.0, with its new rotational tools, was successfully applied to a near-road, high time resolution AMS data set. HOA was a quarter of the OM (24\%), and higher under downwind conditions (about $40 \%$ ). In addition to this local, primary OA, there was a highly oxidized background of OA (LV-OOA) that, on average, constituted $29 \%$ of the OM, and a less oxidized, semi-volatile fraction that accounted for $34 \%$ of the OM. During the evening hours, biomass burning (BBOA) was also seen, likely from the surrounding residential area. Rotational tools allowed for additional analysis of the PMF solution space, increasing our confidence in the results.

\section{Supplementary material related to this article is available online at: http://www.atmos-chem-phys.net/12/309/2012/ acp-12-309-2012-supplement.pdf.}

Acknowledgements. The authors thank the Nevada Department of Transportation, US EPA Office of Research and Development, and Sonoma Technology, Inc., for supporting this work. We also thank Jennifer DeWinter (STI) and Ram Vedantham (EPA ORD) for data analysis support and analysis of the collocated data at Fyfe Elementary, Mary Jo Teplitz (STI) for editorial support, and Bryan Penfold (STI) for the site map. We greatly appreciate the development of the data processing and analysis methods done by the AMS community, particularly by Jose Jimenez and Ingrid Ulbrich (University of Colorado). The acquisition of the CSU Aerosol Mass Spectrometer (AMS) was supported by the NSF-MRI program under grant number ATM-0521643. The AMS was operated in the CSU Mobile Laboratory, which is supported by the National Park Service (NPS).

Edited by: X. Querol

\section{Disclaimer}

The United States Environmental Protection Agency through its Office of Research and Development partially funded the research described here under PO 720002129 to Sonoma Technology, Inc. It has been subjected to Agency review and approved for publication, though the views and opinions of authors expressed herein do not necessarily state or reflect those of the United States Government.

\section{References}

Adonis, M. I., Riquelme, R. M., Martinez, V. D., Gil, L., Rios, C., Rodriguez, L., and Rodriquez, E. M.: PAHs and mutagenicity of inhalable and respirable diesel particulate matter in Santiago, Chile, Polycyc. Aromatic Compounds 23, 495-514, 2003.

Aiken, A. C., DeCarlo, P., Kroll, J. H., Worsnop, D. R., Huffman, J. A., Docherty, K. S., Ulbrich, I. M., Mohr, C., Kimmel, J. R., Sueper, D., Sun, Y., Zhang, Q., Trimborn, A., Northway, M., Ziemann, P. J., Canagaratna, M. R., Onasch, T. B., Alfarra,
M. R., Prevot, A. S. H., Dommen, J., Duplissy, J., Metzger, A., Baltensperger, U., and Jimenez, J. L.: O/C and OM/OC ratios of primary, secondary, and ambient organic aerosols with high-resolution time-of-flight aerosol mass spectrometry, Environ. Sci. Technol., 42(12), 4478-4485, doi:10.1021/es703009q, 2008.

Alfarra, M. R., Coe, H., Allan, J. D., Bower, K. N., Boudries, H., Canagaratna, M. R., Jimenez, J. L., Jayne, J. T., Garforth, A. A., Li, S.-M., and Worsnop D. R.: Characterization of urban and rural organic particulate in the Lower Fraser Valley using two Aerodyne aerosol mass spec20 trometers, Atmos. Environ., 38, 5745-5758, doi:10.1016/j.atmosenv.2004.01.054, 2004.

Alfarra, M. R., Paulsen, D., Gysel, M., Garforth, A. A., Dommen, J., Prévôt, A. S. H., Worsnop, D. R., Baltensperger, U., and Coe, H.: A mass spectrometric study of secondary organic aerosols formed from the photooxidation of anthropogenic and biogenic precursors in a reaction chamber, Atmos. Chem. Phys., 6, 52795293, doi:10.5194/acp-6-5279-2006, 2006.

Alfarra, M. R., Prevot, A. S. H., Szidat, S., Sandradewi, J., Weimer, S., Lanz, V. A., Schreiber, D., Mohr, M., and Baltensperger, U.: Identification of the mass spectral signature of organic aerosols from wood burning emissions, Environ. Sci. Technol., 41, 57705777, doi:10.1021/es062289b, 2007.

Allan, J. D., Alfarra, M. R., Bower, K. N., Williams, P. I., Gallagher, M. W., Jimenez, J. L., McDonald, A. G., Nemitz, E., Canagaratna, M. R., Jayne, J. T., Coe, H., and Worsnop, D. R.: Quantitative sampling using an Aerodyne aerosol mass spectrometer - 2. Measurements of fine particulate chemical composition in two UK cities, J. Geophys. Res.-Atmos., 108(D3), 4091, doi:10.1029/2002JD002359, 2003a.

Allan, J. D., Jimenez, J. L., Williams, P. I., Alfarra, M. R., Bower, K. N., Jayne, J. T., Coe, H., and Worsnop, D. R.: Quantitative sampling using an Aerodyne aerosol mass spectrometer 1. Techniques of data interpretation and error analysis, J. Geophys. Res.-Atmos., 108(D3), 4090, doi:10.1029/2002JD002358, 2003b.

Allan, J. D., Delia, A. E., Coe, H., Bower, K. N., Alfarra, M. R., Jimenez, J. L., Middlebrook, A. M., Drewnick, F., Onasch, T. B., Canagaratna, M. R., Jayne, J. T., and Worsnopf, D. R.: A generalised method for the extraction of chemically resolved mass spectra from Aerodyne aerosol mass spectrometer data, J. Aerosol Sci., 35(7), 909-922, 2004.

Brown, S. G. and Hafner, H. R.: Source apportionment of VOCs in the Houston, Texas, area. Presented at the NARSTO Workshop on Innovative Methods for Emission-Inventory Devel15 opment and Evaluation, Austin, TX, 1416 October (STI-2356), 2003.

Brunekreef, B., Janssen, N. A., de Hartog, J., Harssema, H., Knape, M., and van Vliet, P.: Air 20 pollution from truck traffic and lung function in children living near motorways, Epidemiology, 8(3), 298-303, 1997.

Canagaratna, M. R., Jayne, J. T., Ghertner, D. A., Herndon, S., Shi, Q., Jimenez, J. L., Silva, P. J., Williams, P., Lanni, T., Drewnick, F., Demerjian, K. L., Kolb, C. E., and Worsnop, D. R.: Chase studies of particulate emissions from in-use New York City vehicles, Aerosol Sci. Technol., 38(6), 555-573, 2004.

Canagaratna, M. R., Jayne, J. T., Jimenez, J. L., Allan, J. D., Alfarra, M. R., Zhang, Q., Onasch, T. B., Drewnick, F., Coe, H., Middlebrook, A., Delia, A., Williams, L. R., Trimborn, A. M., Northway, M. J., DeCarlo, P. F., Kolb, C. E., Davi- 
dovits, P., and Worsnop, D. R.: Chemical and microphysical characterization of ambient aerosols with the aerodyne aerosol mass 30 spectrometer, Mass Spectrom. Rev., 26(2), 185-222, doi:10.1002/mas.20115, 2007.

DeCarlo, P., Kimmel, J. R., Trimborn, A., Northway, M., Jayne, J.,T., Aiken, A. C., Gonin, M., Fuhrer, K., Horvath, T., Docherty, K. S., Worsnop, D. R., and Jimenez, J. L.: Fielddeployable, high-resolution, time-of-flight aerosol mass spectrometer, Anal. Chem. (Wash.), 78(24), 8281-8289, doi:10.1021/ac061249n, 2006.

Docherty, K. S., Stone, E. A., Ulbrich, I. M., DeCarlo, P., Snyder, D. C., Schauer, J. J., Peltier, R. E., Weber, R. J., Murphy, S. M., Seinfeld, J. H., Grover, B. D., Eatough, D. J., and Jimenez, J. L.: Apportionment of primary and secondary organic aerosols in Southern California during 5 the 2005 Study of Organic Aerosols in Riverside (SOAR-1), Environ. Sci. Technol., 42(20), 76557662, doi:10.1021/es8008166, 2008.

Dockery, D. W., Pope, C. A., Xu, X. P., Spengler, J. D., Ware, J. H., Fay, M. E., Ferris, B. G., 10 and Speizer, F. E.: An association between air pollution and mortality in six U.S. cities, New Engl. J. Med., 329, 1753-1759, 1993.

Dockery, D. W. and Stone, P. H.: Cardiovascular risks from fine particulate air pollution, New Engl. J. Med., 356, 511-513, http: //content.nejm.org/cgi/content/extract/356/5/511, 2007.

Drewnick, F., Hings, S. S., DeCarlo, P., Jayne, J. T., Gonin, M., Fuhrer, K., Weimer, S., Jimenez, J. L., Demerjian, K. L., Borrmann, S., and Worsnop, D. R.: A new time-of-flight aerosol mass spectrometer (TOF-AMS) instrument description and first field deployment, Adv. Sci. Technol. 39, 637-658, doi:10.1080/02786820500182040, 2005.

Dzepina, K., Arey, J., Marr, L. C.,Worsnop, D. R., Salcedo, D., Zhang, Q., Onasch, T. B., Molina, L. T., Molina, M. J., and Jimenez, J. L.: Detection of particle-phase polycyclic aromatic hydrocarbons in Mexico City using an aerosol mass spectrometer, Int. J. Mass Spectrom., 263, 152-170, doi:10.1016/j.ijms.2007.01.010, 2007.

Edwards, J., Walters, S., and Griffiths, R. K.: Hospital admissions for asthma in preschool children: relationship to major roads in Birmingham, United Kingdom, Arch. Environ. Health, 49, 223227, 1994.

Finkelstein, M. M., Jerrett, M., and Sears, M. R.: Traffic air pollution and mortality rate advancement periods, Am. J. Epidemiol., 160(2), 173-177, 2004.

Flowers, L., Rieth, S. H., Cogliano, V. J., Foureman, G. L., Hertzberg, R., Hofmann, E. L., Murphy, D. L., Nesnow, S., and Schoeny, R. S.: Health assessment of polycyclic aromatic hydrocarbon mixtures: current practices and future directions, Polycyc. Aromatic Compounds, 22, 811-821, 2002.

Fruin, S., Westerdahl, D., Sax, T., Sioutas, C., and Fine, P. M.: Measurements and predictors 30 of on-road ultrafine particle concentrations and associated pollutants in Los Angeles, Atmos. Environ., 42, 207-219, doi:10.1016/j.atmosenv.2007.09.057, 2008.

Green, M. C., Chow, J. C., Hecobian, A., Etyemezian, V., Kuhns, H., and Watson, J. G.: Las Vegas Valley visibility and $\mathrm{PM}_{2.5}$ study. Final Report prepared for the Clark County Department of Air Quality Management, Las Vegas, NV, by the Desert Research Institute, Las Vegas, NV, 2002.

Hand, J. L., Copeland, S. A., Day, D. E., Dillner, A. M., Indresand, H., Malm, W. C., McDade, C. E., Moore, C. T., Pitchford, M. L.,
Schichtel, B. A., and Watson, J. G.: Spatial and seasonal patterns and temporal variability of haze and its constituents in the United States: IMPROVE Report V. June, http://vista.cira.colostate.edu/ improve/publications/reports/2011/2011.htm, 2011.

Hoek, G., Brunekreef, B., Goldbohm, S., Fischer, P., and van den Brandt, P. A.: Association between mortality and indicators of traffic-related air pollution in the Netherlands: a cohort study, Lancet, 360, 1203-1209, 2002.

Hopke, P. K.: A guide to positive matrix factorization. Prepared for the Positive Matrix Factorization Program, Potsdam, NY, by the Department of Chemistry, Clarkson University, Potsdam, NY, 2003.

Hu, S., Fruin, S., Kozawa, K., Mara, S., Paulson, S. E., and Winer, A. M.: A wide area of air pollutant impact downwind of a freeway during pre-sunrise hours, Atmos. Environ., 43, 2541-2549, doi:10.1016/j.atmosenv.2009.02.033, 2009.

Huffman, J. A., Docherty, K. S., Mohr, C., Cubison, M., Ulbrich, I. M., Ziemann, P. J., Onasch, T. B., and Jimenez, J. L.: Chemically-resolved volatility measurements of organic aerosol from different sources, Environ. Sci. Technol., 43, 5351-5357, doi:10.1021/es803539d, 2009.

Jayne, J. T., Leard, D. C., Zhang, X. F., Davidovits, P., Smith, K. A., Kolb, C. E., and Worsnop, D. R.: Development of an aerosol mass spectrometer for size and composition analysis of submicron particles, Adv. Sci. Technol., 33(12), 49-70, 2000.

Jimenez, J. L., Jayne, J. T., Shi, Q., Kolb, C. E., Worsnop, D. R., Yourshaw, I., Seinfeld, J. H., Flagan, R. C., Zhang, X. F., Smith, K. A., Morris, J. W., and Davidovits, P.: Ambient aerosol sampling using the Aerodyne Aerosol Mass Spectrometer, J. Geophys. Res.-Atmos., 108(D7), 8425, doi:10.1029/2001JD001213, 2003.

Jimenez, J. L., Canagaratna, M. R., Donahue, N. M., Prevot, A. S. H., Zhang, Q., Kroll, J. H., DeCarlo, P. F., Allan, J. D., Coe, H., Ng, N. L., Aiken, A. C., Docherty, K. S., Ulbrich, I. M., Grieshop, A. P., Robinson, A. L., Duplissy, J., Smith, J. D., Wilson, K. R., Lanz, V. A., Hueglin, C., Sun, Y. L., Tian, J., Laaksonen, A., Raatikainen, T., Rautiainen, J., Vaattovaara, P., Ehn, M., Kulmala, M., Tomlinson, J. M., Collins, D. R., Cubison, M. J., Dunlea, E. J., Huffman, J. A., Onasch, T. B., Alfarra, M. R., Williams, P. I., Bower, K., Kondo, Y., Schneider, J., Drewnick, F., Borrmann, S., Weimer, S., Demerjian, K., Salcedo, D., Cottrell, L., Griffin, R., Takami, A., Miyoshi, T., Hatakeyama, S., Shimono, A., Sun, J. Y., Zhang, Y. M., Dzepina, K., Kimmel, J. R., Sueper, D., Jayne, J. T., Herndon, S. C., Trimborn, A. M., Williams, L. R., Wood, E. C., Middlebrook, A. M., Kolb, C. E., Baltensperger, U., and Worsnop, D. R.: Evolution of organic aerosols in the atmosphere, Science, 326, 1525-1529, doi:10.1126/science.1180353, 2009.

Johnson, K. S., Laskin, A., Jimenez, J. L., Shutthanandan, V., Molina, L. T., Salcedo, D., Dzepina, K., and Molina, M. J.: Comparative analysis of urban atmospheric aerosol by ParticleInduced X-ray Emission (PIXE), Proton Elastic Scattering Analysis (PESA), and Aerosol Mass Spectrometry (AMS), Environ. Sci. Technol., 42(17), 6619-6624, doi:10.1021/es800393e, 2008.

Kim, E., Hopke, P. K., and Edgerton, E. S.: Source identification of Atlanta aerosol by positive matrix factorization, J. Air Waste Manag. Assoc., 53, 731-739, 2003.

Kim, E. and Hopke, P. K.: Improving source identification of fine particles in a rural northeastern U.S. area utilizing 
temperature-resolved carbon fractions, J. Geophys. Res., 109(D9), D09204, doi:09210.01029/02003JD004199, 2004.

Kim, E., Hopke, P. K., and Edgerton, E. S.: Improving source identification of Atlanta aerosol using temperature resolved carbon fractions in positive matrix factorization, Atmos. Environ., 38, 3349-3362, 2004a.

Kim, J. J., Smorodinsky, S., Lipsett, M., Singer, B. C., Hodgson, A. T., and Ostro, B.: Traffic related air pollution near busy roads: the East Bay Childrens Respiratory Health Study, Am. J. Respir. Crit. Care Med., 170(5), 520-526, 2004b.

Kunzli, N., Kaiser, R., Medina, S., Studnicka, M., Chanel, O., and Filliger, P.: Public-health impact of outdoor and traffic-related air pollution: a European assessment, Lancet, 356, 795-801, 2000.

Lanz, V. A., Alfarra, M. R., Baltensperger, U., Buchmann, B., Hueglin, C., and Prévôt, A. S. H.: Source apportionment of submicron organic aerosols at an urban site by factor analytical modelling of aerosol mass spectra, Atmos. Chem. Phys., 7, 1503-1522, doi:10.5194/acp-7-1503-2007, 2007.

Lanz, V. A., Alfarra, M. R., Baltensperger, U., Buchmann, B., Hueglin, C., Szidat, S., Wehrli, M. N., Wacker, L., Weimer, S., Caseiro, A., Puxbaum, H., and Prevot, A. S. H.: Source attribution of submicron organic aerosols during wintertime inversions by advanced factor analysis of aerosol mass spectra, Environ. Sci. Technol., 42(1), 214-220, doi:10.1021/es0707207, 2008a.

Lanz, V. A., Alfarra, M. R., Baltensperger, U., Buchmann, B., Hueglin, C., Szidat, S., Wehrli, M. N.,Wacker, L.,Weimer, S., Caseiro, A., Puxbaum, H., and Prevot, A. S. H.: Source attribution of submicron organic aerosols during wintertime inversions by advanced factor analysis of aerosol mass spectra, Environ. Sci. Technol., 42, 214-220, doi:10.1021/es0707207, 2008b.

Lanz, V. A., Prévôt, A. S. H., Alfarra, M. R., Weimer, S., Mohr, C., DeCarlo, P. F., Gianini, M. F. D., Hueglin, C., Schneider, J., Favez, O., DAnna, B., George, C., and Baltensperger, U.: Characterization of aerosol chemical composition with aerosol mass spectrometry in Central Europe: an overview, Atmos. Chem. Phys., 10, 10453-10471, doi:10.5194/acp-10-10453-2010, 2010.

Larsen, R. K. and Baker, J. E.: Source apportionment of polycyclic aromatic hydrocarbons in the urban atmosphere: a comparison of three methods, Environ. Sci. Technol., 37(9), 1873-1881, 2003.

Lee, T., Sullivan, A. P., Mack, L., Jimenez, J. L., Kreidenweis, S. M., Onasch, T. B., Worsnop, D. R., Malm, W., Wold, C. E., Hao, W. M., and Jeffrey, L. C. J.: Chemical smoke marker emissions during flaming and smoldering phases of laboratory open burning of wildland fuels, Adv. Sci. Technol., 44(9), iv, doi:10.1080/02786826.2010.499884, 2010.

Lobscheid, A. B. and McKone, T. E.: Constraining uncertainties about the sources and magnitude of polycyclic aromatic hydrocarbon (PAH) levels in ambient air: the state of Minnesota as a case study, Atmos. Environ., 38, 5501-5515, 2004.

McDonald, J. D., Harrod, K. S., Seagrave, J., Seilkop, S. K., and Mauderly, J. L.: Effects of low sulfur fuel and a catalyzed particle trap on the composition and toxicity of diesel emissions, Environ. Health Perspect., 112(13), 1307-1312, 2004.

Minguillon, M. C., Arhami, M., Schauer, J. J., and Sioutas, C.: Seasonal and spatial variations of sources of fine and quasi-ultrafine particulate matter in neighborhoods near the Los Angeles-Long Beach harbor, Atmos. Environ., 42, 7317-7328, 2008.

Mohr, C., Huffman, J. A., Cubison, M., Aiken, A. C., Docherty, K. S., Kimmel, J. R., Ulbrich, I. M., Hannigan, M., and Jimenez,
J. L.: Characterization of primary organic aerosol emissions from meat cooking, trash burning, and motor vehicles with highresolution aerosol mass spectrometry and comparison with ambient and chamber observations, Environ. Sci. Technol., 43(7), 2443-2449, doi:10.1021/es8011518, 2009.

Ng, N. L., Canagaratna, M. R., Zhang, Q., Jimenez, J. L., Tian, J., Ulbrich, I. M., Kroll, J. H., Docherty, K. S., Chhabra, P. S., Bahreini, R., Murphy, S. M., Seinfeld, J. H., Hildebrandt, L., Donahue, N. M., DeCarlo, P. F., Lanz, V. A., Prévôt, A. S. H., Dinar, E., Rudich, Y., and Worsnop, D. R.: Organic aerosol components observed in Northern Hemispheric datasets from Aerosol Mass Spectrometry, Atmos. Chem. Phys., 10, 46254641, doi:10.5194/acp-10-4625-2010, 2010.

Nitta, H., Sato, T., Nakai, S., Maeda, K., Aoki, S., and Ono, M.: Respiratory health associated with exposure to automobile exhaust. 1. Results of cross-sectional studies in 1979, 1982, and 1983, Arch. Environ. Health, 48(1), 53-58, 1993.

Norris, G., Vedantham, R., Wade, K. S., Brown, S. G., Prouty, J. D., and Foley, C.: EPA positive matrix factorization (PMF) 3.0 fundamentals and user guide. Prepared for the U.S. Environmental Protection Agency, Washington, D.C., by the National Exposure Research Laboratory, Research Triangle Park; Sonoma Technology, Inc., Petaluma, CA; and Lockheed Martin Systems Engineering Center, Arlington, VA, EP-D-05-004; STI-907045.053347-UG, October, 2008.

Norris, G., Vedantham, R., Wade, K., Zahn, P., Brown, S., Paatero, P., Eberly, S., and Foley, C.: Guidance document for PMF applications with the Multilinear Engine. Prepared for the U.S. Environmental Protection Agency, Research Triangle Park, NC, by the National Exposure Research Laboratory, Research Triangle Park, NC; Sonoma Technology, Inc., Petaluma, CA; University of Helsinki, Helsinki, Finland; Geometric Tools, Inc., Phoenix, AZ; and Lockheed Martin, Systems Engineering Center, Arlington, VA, EPA 600/R-09/032, April, 2009.

Ntziachristos, L., Ning, Z., Geller, M. D., and Sioutas, C.: Particle concentration and characteristics near a major freeway with heavy-duty diesel traffic, Environ. Sci. Technol., 41(7), 22232230, doi:10.1021/es062590s, 2007.

Paatero P. and Tapper U.: Analysis of different modes of factor analysis as least squares fit problems, Chemometrics Intellig. Lab. Syst., 18, 183-194, 1993.

Paatero P. and Tapper U.: Positive matrix factorization: a nonnegative factor model with optimal utilization of error estimates of data values, Environmetrics, 5, 111-126, 1994.

Paatero, P.: Least squares formulation of robust non-negative factor analysis, Chemometrics Intellig. Lab. Syst., 37, 23-35, 1997.

Paatero, P.: User's guide for the multilinear engine program "ME2" for fitting multilinear and quasi-multilinear models. February, 2000.

Paatero, P.: End user's guide to multilinear engine applications, August, 2004.

Paatero P. and Hopke, P.: Rotational tools for factor analytic models, J. Chemometrics, 23, 91-100, 2009.

Phuleria, H. C., Sheesley, R. J., Schauer, J. J., Fine, P. M., and Sioutas, C.: Roadside measurements of size-segregated particulate organic compounds near gasoline and diesel-dominated freeways in Los Angeles, CA, Atmos. Environ., 41, 4653-4671, doi:10.1016/j.atmosenv.2007.03.031, 2007. 
Poirot, R. L., Wishinski, P. R., Hopke, P. K., and Polissar, A. V.: Comparative application of multiple receptor methods to identify aerosol sources in northern Vermont, Environ. Sci. Technol., 35(23), 4622-4636, 2001.

Polissar, A. V., Hopke, P. K., and Poirot, R. L.: Atmospheric aerosol over Vermont: chemical composition and sources, Environ. Sci. Technol., 35(23), 4604-4621, 2001.

Riddle, S. G., Robert, M. A., Jakober, C. A., Hannigan, M. P., and Kleeman, M. J.: Size-resolved source apportionment of airborne particle mass in a roadside environment, Environ. Sci. Technol., 42(17), 65806586, doi:10.1021/es702827h, 2008.

Roberts, P. T., Brown, S. G., McCarthy, M. C., DeWinter, J. L., and Vaughn, D. L.: Mobile source air toxics (MSATs) at three schools next to U.S. 95 in Las Vegas, Nevada. Prepared for the Nevada Department of Transportation, Las Vegas, NV, by Sonoma Technology, Inc., Petaluma, CA, STI 906034-3509FR2, May 2010.

Sage, A. M., 5 Weitkamp, E. A., Robinson, A. L., and Donahue, N. M.: Evolving mass spectra of the oxidized component of organic aerosol: results from aerosol mass spectrometer analyses of aged diesel emissions, Atmos. Chem. Phys., 8, 1139-1152, doi:10.5194/acp-8-1139-2008, 2008.

Schneider, J., Weimer, S., Drewnick, F., Borrmann, S., Helas, G., Gwaze, P., Schmid, O., Andreae, M. O., and Kirchner, U.: Mass spectrometric analysis and aerodynamic properties of various types of combustion-related aerosol particles, Int. J. Mass Spec., 258(1-3), 37-49, doi:10.1016/j.ijms.2006.07.008, 2006.

Sun, Y., Zhang, Q., Macdonald, A. M., Hayden, K., Li, S. M., Liggio, J., Liu, P. S. K., Anlauf, K. G., Leaitch, W. R., Steffen, A., Cubison, M., Worsnop, D. R., van Donkelaar, A., and Martin, R. V.: Size-resolved aerosol chemistry on Whistler Mountain, Canada with a highresolution aerosol mass spectrometer during INTEX-B, Atmos. Chem. Phys., 9, 3095-3111, doi:10.5194/acp9-3095-2009, 2009.

Ulbrich, I. M., Canagaratna, M. R., Zhang, Q., Worsnop, D. R., and Jimenez, J. L.: Interpretation of organic components from Positive Matrix Factorization of aerosol mass spectrometric data, Atmos. Chem. Phys., 9, 2891-2918, doi:10.5194/acp-9-2891-2009, 2009a.
Ulbrich, I. M., Lechner, M., and Jimenez, J. L.: AMS spectral database (unit mass resolution). Jimenez Group, University of Colorado, Boulder, CO, available at: http://cires.colorado.edu/ jimenez-group/AMSsd/, 2009b.

Weimer, S., Alfarra, M. R., Schreiber, D., Mohr, M., Prevot, A. S. H., and Baltensperger, U.: Organic aerosol mass spectral signatures from wood-burning emissions: influence of burning conditions and wood type, J. Geophys. Res.-Atmos., 113, D10304, doi:10.1029/2007JD009309, 2008.

Zhang, K. M., Wexler, A. S., Zhu, Y. F., Hinds, W. C., and Sioutas, C.: Evolution of particle number distribution near roadways. Part II: The "road-to-ambient" process. Atmos. Environ. 38, 66556665, 2004a.

Zhang, Q., Stanier, C. O., Canagaratna M. R., Jayne, J. T., Worsnop, D. R., Pandis, S. N., and Jimenez, J. L.: Insights into the chemistry of new particle formation and growth events in Pittsburgh based on aerosol mass spectrometry, Environ. Sci. Technol., 38 (18), 4797-4809, 2004b.

Zhang, Q., Alfarra, M. R., Worsnop, D. R., Allan, J. D., Coe H., Canagaratna, M. R., and Jimenez, J. L.: Deconvolution and quantification of hydrocarbon-like and oxygenated organic aerosols based on aerosol mass spectrometry. Environ. Sci. Technol. 39, 4938-4952, doi:10.1021/es0485681, 2005a.

Zhang, Q., Worsnop, D. R., Canagaratna, M. R., and Jimenez, J. L.: Hydrocarbon-like and oxygenated organic aerosols in Pittsburgh: insights into sources and processes of organic aerosols, Atmos. Chem. Phys., 5, 3289-3311, doi:10.5194/acp-5-32892005, 2005.

Zhu, Y. F., Hinds, W. C., Kim, S., and Sioutas, C.: Concentration and size distribution of ultrafine particles near a major highway, J. Air Waste Manage. Assoc., 52(9), 1032-1042, 2002. 